Portland State University

PDXScholar

7-11-1997

\title{
A Pouplation Genetic Study of Wild Bottlenose Dolphins (Tursiops truncatus) in Matagorda Bay, Texas
}

Joel Stephen Lenox

Portland State University

Follow this and additional works at: https://pdxscholar.library.pdx.edu/open_access_etds

Part of the Biology Commons

Let us know how access to this document benefits you.

\section{Recommended Citation}

Lenox, Joel Stephen, "A Pouplation Genetic Study of Wild Bottlenose Dolphins (Tursiops truncatus) in Matagorda Bay, Texas" (1997). Dissertations and Theses. Paper 5318.

https://doi.org/10.15760/etd.7191

This Thesis is brought to you for free and open access. It has been accepted for inclusion in Dissertations and Theses by an authorized administrator of PDXScholar. Please contact us if we can make this document more accessible: pdxscholar@pdx.edu. 


\section{THESIS APPROVAL}

The abstract and thesis of Joel Stephen Lenox for the Master of Science in

Biology were presented July 11, 1997, and accepted by the thesis committee and the department.

COMMITTEE APPROVALS:

Deborah Duffield, Chair

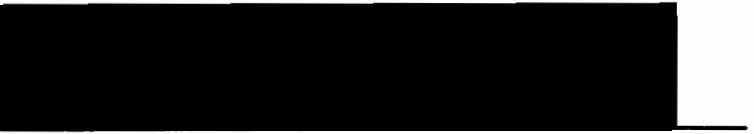

Richard Forbes

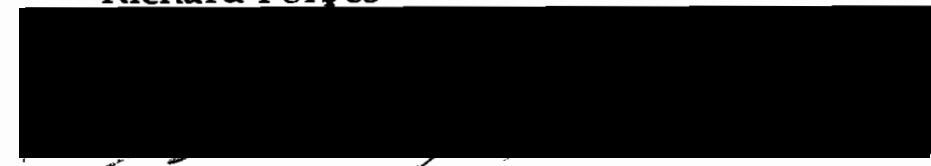

- Lester Newman'

DEPARTMENT APPROVAL:

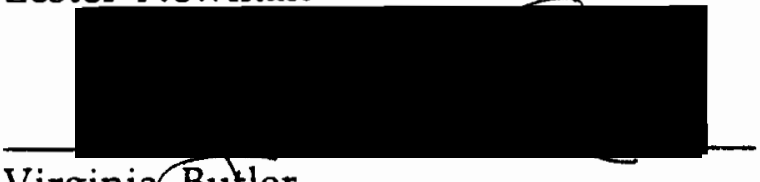

Virginia Butier

Representative of the Office of

Graduate Studies

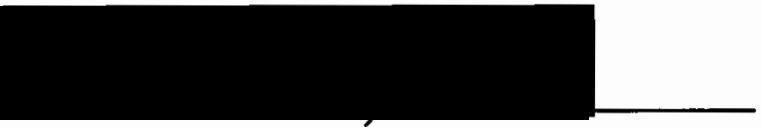

Leonard Simpson, Chair

Department of Biology

ACCEPTED FOR PORTLAND STATE UNIVERSITY BY THE LIBRARY

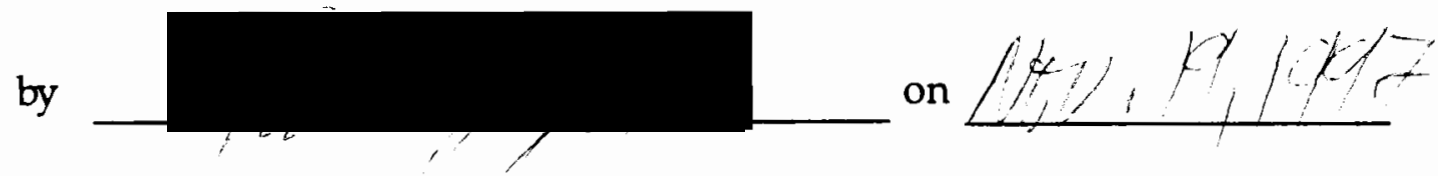




\section{ABSTRACT}

An abstract of the thesis of Joel Stephen Lenox for the Master of Science in Biology presented July 11, 1997.

Title: A Population Genetic Study of Wild Bottlenose Dolphins (Tursiops truncatus) in Matagorda Bay, Texas

A long-term photoidentification study was initiated in response to an unusually high incidence of bottlenose dolphin mortality between Corpus Christi and Matagorda Bays, Texas. Blood samples from 36 captured and released animals were analyzed using three genetic techniques; mtDNA haplotyping, nuclear DNA fingerprinting and electrophoretic analysis of hemoglobin. Two Hinf I mtDNA haplotypes previously described in bottlenose dolphins from other locations within the Gulf of Mexico were discovered. Similarity Indices (SI) were calculated based on nuclear DNA fingerprinting data. These SI values were used as a relative measure of relatedness between two individuals run on the same gel. Means of pairwise similarity indices were determined for the overall sample and various subgroupings. These subgroupings were based on such factors as sex, reproductive condition, mtDNA haplotypes and behavioral characteristics. All but one of the samples had hemoglobin profiles characteristic of inshore dolphins. The one exception was an 
individual with a hemoglobin profile reflecting an intrusion of offshore alleles into this population.

A significant difference was revealed between the mean SI values for subgroupings based on the two mtDNA haplotypes. Further analysis revealed a correlation between this division and an observed behavioral partitioning. These data suggest a division in the samples characteristic of an inshore or locally resident group and an offshore or more migratory group. Differences in learned foraging strategies are proposed as a possible explanation for observed differences in philopatry between the two groups of animals. Inshore and offshore animals are not believed to be genetically isolated based on hemoglobin data previously mentioned and findings from a separate study of chromosomal markers. Evidence for genetic exchange between neighboring communities is found in a review of the literature pertaining to migration capabilities of the species. A clinal distribution pattern of mtDNA haplotypes seen throughout the Gulf of Mexico and along the south-eastern Atlantic seaboard is presented. A potential correlation is drawn between haplotype distribution patterns and major oceanographic features. Studies of specific geographical regions, such as the one undertaken in Matagorda Bay, are deemed useful for the future mapping of population subdivisions and stock definition throughout the Gulf of Mexico. 
A POPULATION GENETIC STUDY OF WILD BOTTLENOSE

DOLPHINS (TURSIOPS TRUNCATUS) IN MATAGORDA BAY, TEXAS

by

JOEL STEPHEN LENOX

A thesis submitted in partial fulfillment of the requirements for the degree of

\author{
MASTER OF SCIENCE \\ in \\ BIOLOGY
}

Portland State University

1997 


\section{ACKNOWLEDGMENTS}

I would like to begin by thanking Dr. Deborah Duffield for her support as both friend and advisor throughout this entire process. In addition to providing the majority of the resources for this project she has been a constant source of encouragement and enthusiasm.

Secondly, I would like to extend my gratitude to the members of my thesis committee, Dr. Lester Newman, Dr. Virginia Butler and especially Dr. Richard Forbes for his meticulous review of the initial draft of this document. Thanks also to Larry Hansen for providing the very samples which made this study possible. Kudos to all of my fellow lab-mates: Peg, Kristine, Leslie and of course Dr. David Hayteas for his unending wit and wisdom throughout the years. A special thank you to Angelika Grossmann for her support, advice and encouragement during the writing and defense of this thesis.

It would be unthinkable not to mention my family and friends for always being there for me when I needed them. I am truly blessed with family who are friends and friends who are like family. I would like to dedicate this work to my wife Lynly for her unwavering support and help through all the highs and lows of this project.

Finally, thanks be to God, who has shown once again that miracles can occur with the completion of this thesis! 


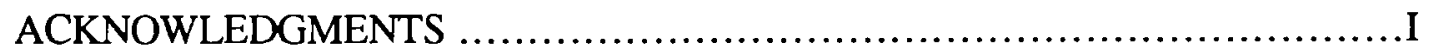

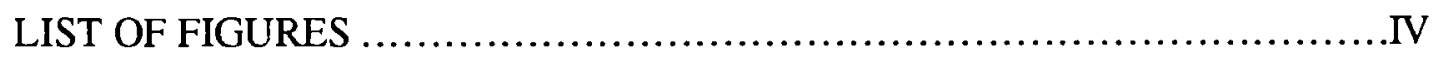

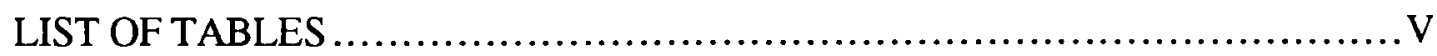

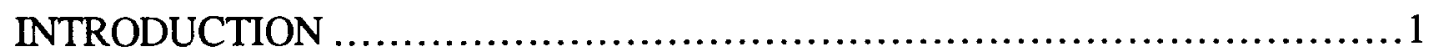

Life History and Distribution .......................................

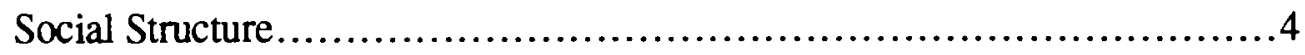

Mating System ............................................................ 5

Stock Differentiation ................................................ 6

Matagorda Study: Why it Started ......................................... 8

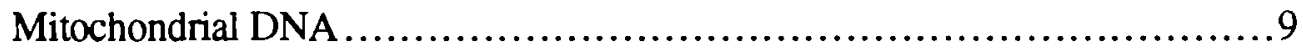

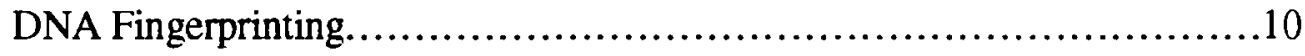

Hemoglobin Electrophoresis...........................................13

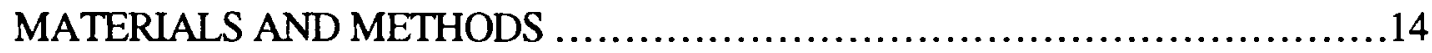

Animals.................................................................

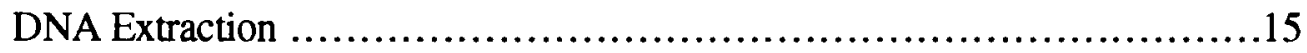

MtDNA Analysis .......................................................

Nuclear DNA Fingerprinting........................................... 16

Statistics ............................................................. 18

Hemoglobin Electrophoresis..........................................19

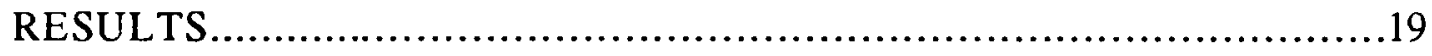

Mitochondrial DNA ................................................. 19

Nuclear DNA Fingerprinting...........................................20

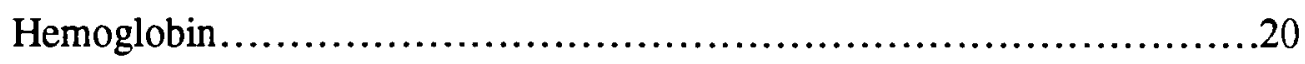




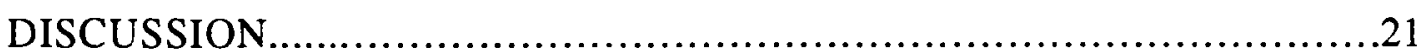

Summary of Matagorda Community .................................21

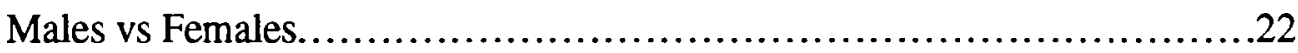

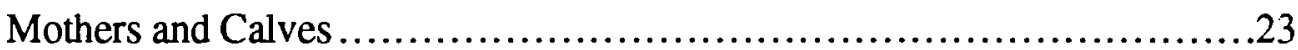

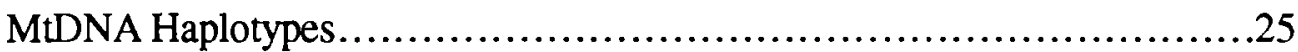

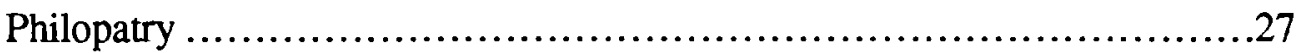

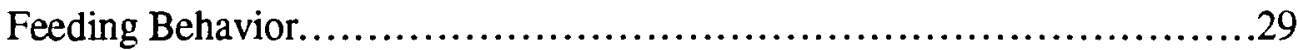

Evidence for Gene Flow Between Groups...............................30

Home Range and Migration Distances...................................31

Mitochondrial DNA Dispersal Patterns in the Gulf of Mexico.................33

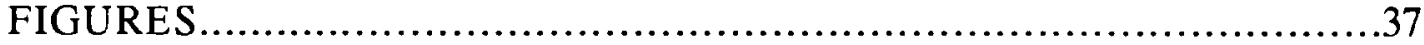

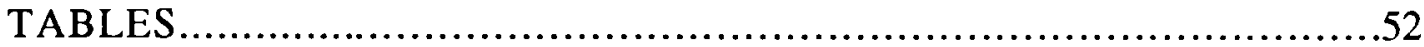

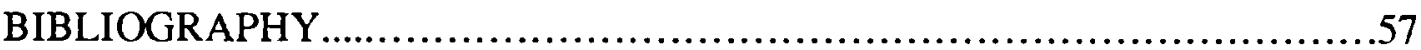

APPENDICES

Total DNA Extraction from Blood ...................................67

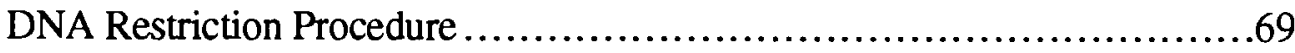

Agarose Gel Preparation.............................................. 71

Nick-Translation........................................................

Southem Transfer ......................................................74

Material Required for DNA Extraction from Whole Blood...................82

Stock Solutions for DNA Extraction..................................83

Equipment Required for Southern Transfer..............................85

Solutions Required for Southern Transfer ............................. 85

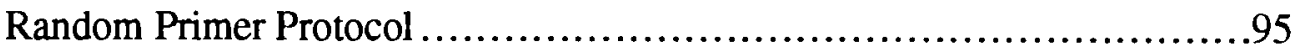




\section{LIST OF FIGURES}

\section{FIGURE}

1. Map of the Port O'Connor area of Matagorda Bay .................. 37

2. Mitochondrial DNA (mtDNA) Hinf I............................ 38

3. Autoradiographs and similarity index matrix: Hinf I, gel A ............ 39

4. Autoradiographs and similarity index matrix: Hinf I, gel B ........... 40

5. Autoradiographs and similarity index matrix: Hinf I, gel C .......... 4l

6. Autoradiographs and similarity index matrix: Alu I, gel A...........42

7. Autoradiographs and similarity index matrix: Alu I, gel B........... 43

8. Autoradiographs and similarity index matrix: Alu I, gel C............ 44

9. Hemoglobin electrophoretic profiles for coastal, offshore,

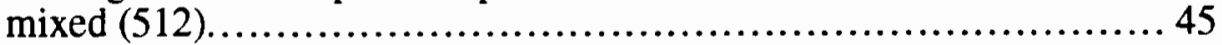

10. Similarity index graphs: males with females: Alu I and Hinf I ........ 46

11. Similarity index graphs: males and mothers with calves: Alu I and Hinf I

12. Similarity index graphs: Mitochondrial Haplotypes: Alu I and Hinf I... 48

13. Similarity index graphs: Group of 10 not seen again:

Alu 1 and Hinf 1

14. Geographic distribution of mtDNA Hinf 1 haplotype frequencies...... 50

15. Major water current patterns.................................... 51 


\section{LIST OF TABLES}

\section{TABLE}

1. Demographic, capture site and mtDNA data ....................... 52

2. Composition of captured groups of dolphins........................ 53

3. Means of pairwise Similarity Index values ......................... 54

4. Statistical analysis summary of dolphins sampled in Matagorda Bay ... 55

5. Pairwise SI's for presumed mother-calf combinations................ 56 


\section{INTRODUCTION}

In recent years the Southeastern National Marine Fisheries Service has been concerned with the issues of local stocks of bottlenose dolphins (Tursiops truncatus) in the Gulf of Mexico and how best to manage the live-capture fishery. Concern has also been raised over large scale die-offs of these dolphins. This study seeks to add our knowledge of the genetic variability of this species in the Gulf by developing and analyzing population genetic data from an ongoing tag and resighting study of bottlenose dolphins in Matagorda Bay, Texas. Data developed included mtDNA haplotypes, nuclear DNA fingerprinting and electrophoretic analysis of hemoglobin profiles.

\section{Life History and Distribution}

Bottlenose dolphins are distributed throughout the oceans of the world in temperate to tropical waters. Twenty specific names have been assigned to the genus at various times in the past (Hershkovitz 1966). In the Pacific Ocean, bottlenose dolphins can be found from northern Japan and southern California to Australia and Chile, and in the Atlantic from Nova Scotia and Norway to Patagonia and the tip of South Africa. They are also commonly observed in the Mediterranean and Indian Oceans. (Leatherwood \& Reeves 1983) 
Presently, around the coastal U.S. at least two different ecotypes are recognized a smaller, more slender, inshore form and a larger, more robust, offshore form (Walker 1981; Duffieldet al. 1983; Hersh \& Duffield 1990). The two are also distinguished by differences in hematological characteristics and morphological characteristics. However, all bottlenose dolphins are currently considered to be one cosmopolitan species with regional subspecies, populations and/or ecotypes. The coastal form is usually found shorewards of the 10 fathom curve in resident or migratory groups. Offshore forms can be found well past the continental shelves in very deep water, but also move close to and through the coastal zones seasonally (Leatherwood \& Reeves 1983; Mead \& Potter 1990; see additional papers in Leatherwood \& Reeves 1990). Group size varies greatly with numbers ranging from 1 to 100 . Herds as large as 1000 animals have been reported (Saayman \& Tayler 1973), but inshore sightings are usually of 2-15 animals. Resident populations, as exemplified by a resident community documented from Sarasota Bay, Florida, consist of 60-100 individuals (Irvine \& Wells 1972; Irvine et al. 1981; Wells et al. 1980, 1987; Scott et al. 1990; Wells 1991). The larger herds are more typical of the migratory inshore and pelagic offshore forms (Leatherwood \& Reeves 1983, 1990).

Bottlenose dolphins range in body size from $3 \mathrm{~m}$ for the adult inshore animals to $4 \mathrm{~m}$ for the larger offshore animals. Males are 
believed to reach sexual maturity between 10-12 years of age while females mature at 5-12 years (Wells et al. 1987). In the animals around Sarasota Bay, Florida, calving is somewhat seasonal with a primary peak occuring in spring and early summer and a secondary peak in late summer early fall (Scott et al . 1990). Although found at similar latitudes to the Sarasota community, animals off the coast of Texas exhibit a calving peak from February to May (Urian et al. 1996) Bottlenose dolphins are spontaneous ovulators with the potential to cycle repeatedly in one season. Gestation is 12 months and females have a calving interval of approximately 2 to 3 years. Lactation is between 12 18 months. Calves usually remain with their mothers for about 3 years, but periods of 9-10 years have been recorded (Wells et al. 1987; Scott et al. 1990; Wells 1991). The association between calf and mother usually decreases gradually after the calf is 3 to 4 years old. The average lifespan for dolphins in the wild is approximately 25 years. The oldest reported ages for females and males are 46 and 34 years respectively.

The species is highly opportunistic in its prey selection and feeding behaviors, eating a wide range of fish and invertebrates. This characteristic has been described by Shane as "behavior flexibility" and is thought to be one of the reasons for the species ability to survive in diverse habitats (Shane 1990 a,b; Van Waerebeek et al. 1990). 
Social Structure

Studies of social structure in captive bottlenose dolphins describes a relatively straight forward dominance heirarchy with the largest adult males being the alpha-class (Shane et al. 1986) In the wild, however, where there is greater spatial separation between groups of animals based on age and sex, male dominance does not appear to be the most prevalent factor in the establishment of social systems.

An on-going long term study of a resident community of bottlenose dolphins in Sarasota Bay on the west coast of Florida described a community system based on a number of female groups (Irvine \& Wells 1972; Irvine et al. 1981; Wells et al. 1980, 1987; Scott et al. 1990; Wells 1991). Membership within a particular female group appears to be established primarily on a long-term social association basis. Within these groups, specific associations are formed around reproductive condition such as pregnancy and caring for calves. Familial relationships also play a role in determining association. These groups or bands of females show a high degree of site fidelity to certain "core areas" within the Sarasota and Tampa Bay areas (Wells et al. 1987). Female core areas were found to overlap. Adult males, on the other hand, tended to travel alone or in tight pair bonds with one or two other adult males. In this study, male-male pairs were found to have the closest affinities of any social unit except for mothers and calves. 
Subadult animals formed both single and mixed-sexed groups with males consistently outnumbering females. One factor possibly contributing to this imbalance is the earlier onset of sexual maturity in females and their subsequent incorporation into the female core groups. Upon reaching sexual maturity most females rejoin their natal groups. (Shane et al. 1986; Wells et al. 1987)

Using a number of genetic techniques combined with long-term behavioral and observational data, Duffield and Wells (1991) concluded that although there existed a high degree of female-group and social unit site fidelty the Sarasota community was highly genetically heterogeneous. They suggest this is due to males moving outside of their normal community ranges and between communities. A $40 \%$ reproductive exchange rate was calculated, based on paternity analysis, for the calves of the Sarasota community suggesting that females are mating with neighboring or migratory males on occasion (Duffield \& Wells 1997 a).

\section{Mating System}

The lack of evidence for pair bond formation between males and females suggests promiscuity as the most likely mating system. Two patterns of association were characterized for adult males with females (Wells et al. 1987). The first involved lone, adult males remaining 
within areas frequented by all of the female groups. Alternatively, roving pairs of adult males traveled throughout and sometimes beyond the community associating with small groups or single adult females at a time. Priority attention by the males was given to those groups of females which were most receptive, namely those not pregnant or with calves. Subadult males had similar and overlapping home ranges with adult females but usually remained segregated from the female groups spending more time at the periphery of these ranges, although female bands have been observed socializing with subadult males.

\section{Stock Differentiation}

Deciding whether or not geographically separated populations of bottlenose dolphins are distinct from each other or whether they are part of an inclusive overall population range has been the task of stock management policies. In his chapter, Management-Oriented Research on Bottlenose Dolphins by the Southeast Fisheries Center Scott (1990) states, "Although longterm residency within coastal ecosystems may be interpereted as supporting the hypothesis that there are resident geographically local stocks of Tursiops truncatus throughout southeast U.S. waters, this condition is neither sufficient nor necessary to prove that these animals are genetically isolated from the balance of the wild gene pool." To get at this issue in more detail, the Southeast Fisheries 
Center (SEFC) employed two lines of investigation to define stock units. These were tag and resighting surveys and molecular genetic studies. The ultimate goal of the SEFC was to use data from these studies to design future management policies.

Tag and resighting studies were carried out at various locations throughout the Gulf including Indian and Banana rivers (Asper \& Odell 1980, Odell \& Asper 1982) Sarasota Bay (Wells et al. 1981), in the Mississippi Sound (Solangi \& Dukes 1983), and more recently, in Matagorda Bay, Texas (Wursig \& Lynn 1996). Dolphin groups were captured using seine nets and individually marked using either freezebranding, fin-notching, roto-tagging or a combination of these. Data were gathered on morphometrics, and blood samples were collected. Resighting efforts included systematic and random design boat surveys and land based surveys. The earlier genetic studies suggested that although there was evidence supporting genetic differentiation of localized populations in all of these areas, populations were not genetically isolated and that there existed some as yet unmeasured rate of exchange among them (Duffield \& Wells 1986; Duffield \& Wells 1991; Duffield et al. 1994).

The SEFC adopted a conservative management plan centered around the idea of local or resident stocks with transitional stocks moving between local stocks. Six management areas (including six 
subareas) were designated, each thought to contain populations representing a separate stock of dolphins (Scott 1990).

\section{Matagorda Study: Why it Started}

A long term photo-identification study was initiated along the Gulf coast of Texas in 1992, after an episode of unusually high dolphin mortality (Wursig \& Lynn 1996). Carcasses of 111 bottlenose dolphins were found between Matagorda and Corpus Christi Bays, from MarchApril 1992, a significant increase from an average of 14 /year calculated for the same time period for the previous five years. This photoidentification research was to be carried out through the Marine Mammal Research Program of Texas A\&M University at Galveston, (Wursig \& Lynn 1996). In addition to long term photo-identification studies, 36 animals were handled in a capture release program sponsored by the National Marine Fisheries Service (July 4-19, 1992). Individual animals were marked using dorsal fin roto tags and freeze branding. Ten of these were fitted with radio-transmitters (Wursig \& Lynn 1996). Blood samples were drawn for reproductive analysis and health assessment. The researchers recommended doing genetic studies similar to those being carried out on the Sarasota resident dolphin population in order to make future comparisons of local population structure and dynamics possible across the proposed stock management 
units. These blood samples were made available to me for genetic analysis.

Three genetic techniques were used to examine the population structure of the dolphins in this area: mitochondrial DNA (mt DNA) haplotype analysis, nuclear DNA fingerprinting, and hemoglobin electrophoresis. Mitochondrial DNA haplotypes were characterized to assess the variability of maternal lineages within the study area. DNA fingerprinting was carried out to develop a relative picture of the relatedness within this potentially resident community. Hemoglobin electrophoresis was used to check for the intrusion of offshore alleles into this onshore "resident" area.

\section{Mitochondrial DNA}

In addition to nuclear DNA markers, mitochondrial DNA (mtDNA) has become a very useful tool in population studies. Its pattern of maternal inheritance and extensive intraspecific polymorphism allows it to be used to investigate the evolutionary history of populations and to document long-term movement and exchanges of individuals between populations apart from the effects of nuclear genetic exchange (see reviews in Avise et al. 1987; Harrison 1989; Palumbi et al. 1991; Avise 1994; Moritz 1994). 
With specific reference to marine mammals, mtDNA has been used to look at questions of species and stock differentiation, and to examine geographic patterns of population distribution and mtDNA gene flow within species (Stevens et al. 1989; Baker et al. 1990; Dizon et al. 1991; Hoezel 1991; Schaeff et al. 1991; Wada 1991; Baker et al. 1993; Dowling \& Brown 1993; Cronin et al. 1994; Maldonado et al. 1995; Boskovic et al 1996; Lamont et al. 1996; McMillan \& Bermingham 1996; Stanley et al. 1996). In wild populations, where observational data are being collected, mt DNA can be used as an initial screening test for potential kinship bonds by identifying individuals sharing common $\mathrm{mt}$ DNA haplotypes (Duffield pers. comm.) On the other hand, mt DNA haplotypes can also be used to exclude kinship, as in cases where dissimilar haplotypes do not confirm presumed mother-calf associations.

\section{DNA Fingerpinting}

Methods for analyzing individual differences at the level of DNA were developed starting in the mid 1970's (Southern 1975; Jeffreys et al . 1985). These methods take advantage of restriction enzymes capable of cutting the DNA at sites where there are short, specific sequences usually four to six nucleotides in length (Lederberg \& Meselson 1964; Meselson 
\& Yuan 1968). DNA isolated from any available source can be cut into multiple fragments using one or more restriction enzymes. These fragments can be separated by size on agarose or polyacrylamide gels and blotted onto nylon membranes (Maniatis et al. 1982) The fragments are made visible by the use of probes (Aquadro et al. 1992). These probes are often pieces of DNA which have been isolated, and cloned from a region of interest in either nuclear or mitochondrial DNA. Applying the probes to the membrane-bound DNA yields a unique pattern of fragments or "bands" for each individual, hence the term "genetic or DNA fingerprint."

Some of the earliest DNA fingerprinting probes were hypervariable minisatellites (Jeffreys et al. 1985). These were short nucleotide sequences (10-60 bp) which appeared throughout the genome in sets of 'tandem repeats.' At each end of the minisatellite sequence was a restriction site. Nakamura et al. (1987) used the term, variable number of tandem repeats (VNTR), to denote a single locus composed of tandem repeats. A number of VNTR loci have been discovered and developed for use as genetic markers (Watson et al. 1992).

One type of VNTR probe currently used in population genetics is the multilocus probe (Gilbert et al .1991; Bruford et al. 1992; Lehmen et al. 1992; Stephens et al. 1992; Wickings 1993; Kappe et al. 1995). 
Multilocus (or heterologous) probes bind to several different VNTR loci and produce individual, highly (or 'hyper') variable band patterns.

Although the multilocus VNTR do not delineate specific gene products they do demonstrate heritability and can be used to calculate the relative degree of band or fragment sharing between individuals (Hedrick \& Miller 1992). With the exception of monozygotic twins, the mean bandsharing between any two individuals is $20 \%$ in humans (Bruford et al. 1992). In other mammalian species, the degree of band sharing for unrelated animals ranges from $26 \%$ in the Asian elephant (Bischof \& Duffield 1994), to $49 \%$ in Serengeti lions (Gilbert et al. 1991) and can be as high as $67-81 \%$ in some species, such as West Indian manatees (Duffield et al. 1997 b). A low degree of band sharing between individuals provides a great deal of inter- and intra-population discrimination.

The proportion of fragments shared between individuals is termed the "Similarity Index" (also refered to as average percent difference or coefficient of band sharing) and has been shown to correlate positively with relatedness.

This similarity index has been shown to be effective in the determination of parentage and estimation of the degree of relatedness. In particular, population genetic studies of both wild and captive animals have used similarity index values (SI's) to descriminate 
between first degree relatives and unrelated animals (Gilbert et al. 1991; Bischof \& Duffield 1994).

\section{Hemoglobin Electrophoresis}

Coastal bottlenose dolphins from the Gulf of Mexico and Florida have a single, electrophoretically "fast" hemoglobin, whereas offshore bottlenose dolphins in the Northwest Atlantic (occasionally found in coastal waters) have two elecrophoretically distiguishable hemoglobins (Hersh \& Duffield 1990). One of these hemoglobins is equivalent to the "fast" hemoglobin of the inshore dolphins; the other is an electrophorectically "slow" hemoglobin. The slow hemoglobin is $70 \%$ of the total hemoglobin in the offshore dolphin, the fast $30 \%$. In a study of 66 captive bottlenose dolphins, Duffield and Chamberlin-Lea (1990) found that a $65 \%$ fast : $35 \%$ slow hemoglobin electrophoretic pattern resulted from matings between dolphins with $100 \%$ fast hemoglobin (inshore) and those with $30 \%$ fast : $70 \%$ slow hemoglobins (offshore). The authors concluded from this that wild dolphins that exhibit the $65 \%$ fast : $35 \%$ slow pattern would also have come from matings between animals of these two hemoglobin types. Four out of 62 wild caught dolphins from the Gulf of Mexico and east coast Florida exhibited this $65 \%$ fast : $35 \%$ slow hemoglobin pattern, which suggested infrequent but occasional gene flow between coastal and offshore dolphin populations. 
These three genetic techniques-mtDNA analysis, nuclear DNA fingerprinting and hemoglobin electrophoresis-were used to investigate the population and community structure of the Matagorda Bay bottlenose dolphins.

\section{MATERIALS AND METHODS}

Animals

Thirty-six bottlenose dolphins from a live capture, tag-release study in Matagorda/Espirito Santo Bays were analysed. The animals were captured over a ten day period from $7 / 9-7 / 19 / 92$. Capture locations are shown in Fig. 1. Demographic data on these 36 animals (16 females:20 males) are summarized in Table 1. Age estimates based on tooth-aging studies (Hohn 1990) indicated that the animals ranged from calves, 2 years of age to adults 20-40 years of age.

Five to $10 \mathrm{cc}$ of whole blood were collected from each animal by venipuncture on the ventral aspect of the fluke and transferred to heparinized Vacutainer blood tubes, stored under refrigeration, and sent within 3-4 days of collection by overnight service to Portland State University. 


\section{DNA Extraction}

Total DNA was extracted from the white blood cells and platelets by treatment with proteinase- $K$, followed by phenol/chloroform extraction and cold ethanol precipitation (Appendices pg. 67). The DNA was centrifuged, dried and resuspended in TE (Tris-HCL/EDTA pH 8.0) and the concentration was checked using a spectrophotometer (Beckman DU-40 Spectrophotometer, Beckman Instruments, Redmond, WA). Samples were diluted to a final concentration of approximately $1 \mathrm{ug} / \mathrm{ul}$ in TE.

\section{MtDNA Analysis}

Restriction enzyme Hinf I was used to cut the DNA for mtDNA haplotype analysis. This enzyme was selected because it showed the greatest variaton in a previous study of mtDNA haplotypes in the Gulf of Mexico (Dowling \& Brown 1993). Enzymatic restriction of 5 ug of DNA was carried out using 2-3 units of Hinf I restriction enzyme for each ug of DNA. The reaction was carried out at 37 degrees $C$ for 4-5 hours before samples were loaded onto a $1.0 \%$ agarose gel. The samples were electrophoresed in $1 \mathrm{X}$ TBE buffer at 40 volts for 8-12 hrs, as per Stevens et al. (1989). As with elecrophoretic isolation of any molecule, the distance the individual pieces of DNA migrated within the gel was dependent on the overall charge on the molecule and its size. After 
electrophoresis, the DNA was transfered from the gel to a nylon membrane and cross-linked to the membrane with UV light (Appendices pg. 74).

Membrane bound mitochondrial DNA was probed with Commerson's dolphin mtDNA (kindly provided to Dr. Duffield's lab by S. Southern of the University of California, San Diego), labeled with biotin-7-dATP. This probe consisted of almost the entire mtDNA genome of the Commerson's dolphin (Cephalorhynchyus commersonii) cloned into five separate fragments using the plasmid, pACYC 184 (Southern et al. 1988, Stevens et al. 1989). Each fragment was labelled with biotin-7-dATP using a nick translation kit (Bethesda Reasearch Laboratories, Life Technologies, Inc., Gaithersburg, Maryland 20898) according to manufacture's instructions. The biotin labeled probe was then hybridized to the DNA bound to the membrane and visualized using the BluGENE nonradioactive Nucleic Acid Detection System (BRL). Each mtDNA blot was photographed to provide a permanent record, as there was a significant decrease in the intensity of the bands on the original membranes over time.

\section{Nuclear DNA Fingerprinting}

Restriction enzymes Hinf I and Alu I were used to cut the DNA for DNA fingerprinting analysis. Similar to the mtDNA analysis 
procedure, enzymatic restriction of 5 ug of DNA was carried out using 23 units of restriction enzyme for each ug of DNA. The reaction was carried out at 37 degrees $C$ for $4-5$ hours, after which samples were loaded onto a $0.8 \%$ agarose gel and electrophoresed in $1 \mathrm{X}$ TBE buffer at 40 volts for approximately $25 \mathrm{hrs}$. The DNA was transfered from the gel to a nylon membrane and cross-linked to the membrane with UV light (Appendices pg. 74).

Due to the lack of proper equipment and facilties for handling radioactivity in our laboratory, DNA-bound membranes were sent to Robert Sheehy at the University of Arizona to be visualized using the hypervariable minisatellite pV47-2 (courtesy of J. L. Longmire, Los Alamos National Laboratory, New Mexico). Random primer labeling of ${ }^{32} \mathrm{P}$ dCTP was performed on the probe which was then hybridized to the membrane-bound DNA (Appendices pg. 95). Membranes were then exposed to X-ray film and the autoradiograms were sent back to Portland State for analysis. A nonradioactive, chemiluminescent technique (GENIUS System, Boehringer Mannheim, Indianapolis, IN 46250) for detecting bands on the DNA membranes was tried in our laboratory, but it did not prove to be sensitive enough for an in-depth analysis of the DNA fragments. Because of this, the autoradiographs prepared by Bob Sheehy were used to evaluate relatedness. Band Score sheets were developed for each gel indicating the presence or absence of bands at 
every fragment position. These represented an individual animal's DNA fingerprint.

Individual DNA fingerprints were compared by calculating pairwise similarity index (SI) values. The SI value is the coefficient of bandsharing between individuals based on the following calculation; $2 \mathrm{~N}_{\mathrm{AB}} /[$ $\mathrm{N}_{A}+\mathrm{N}_{B}$ ] where $\mathrm{N}_{\mathrm{A}}$ is the number of fragments scored in individual $A$, $N_{B}$ is the number of fragments scored in individual $B$, and $N_{A B}$ is the number of fragments shared by both (Lynch 1991). Due to differences in separation and migration of bands between gels, only animals run on the same gel were compared.

\section{Statistics}

Unpaired t-test (InStat 2.03, GraphPad Software, Inc., SanDiego, CA.) were performed on mean SI's of sub-groupings within the Matagorda Bay sample set. These sub-groups were based on such differences as sex, mtDNA haplotype and behavioral observations. The null hypothesis of this test is that the means of the two groups compared are equal. Differences between two groups resulting in $p$ values less than 0.05 were considered significant. 
Hemoglobin Electrophoresis

Red blood cells were preserved in $40 \%$ buffered glycerol (19.5 g potassium citrate, $3.6 \mathrm{~g}$ potassium phosphate dibasic, 2.82 potassium phosphate monobasic, $400 \mathrm{ml}$ glycerol, $600 \mathrm{ml}$ water) and frozen prior to analysis. Hemolysates were prepared by dilution of an aliquot of the buffered red blood cells with three parts water. Cellulose acetate electrophoresis (Helena Laboratories, Beaumont, TX 77704) was done at $\mathrm{pH} 7.6$, using a Tris-EDTA-boric acid buffer (10.2 $\mathrm{g}$ Trisma base, $0.6 \mathrm{~g}$ EDTA, $3.2 \mathrm{~g}$ boric acid, 1 liter of water), and run at $300 \mathrm{~V}$ for 10 minutes. Cellulose acetate plates were then stained with Ponceau S (Helena Laboratories) to identify the hemoglobin (Duffield 1990; Hersh \& Duffield 1990).

\section{RESULTS}

\section{Mitochondrial DNA}

To date, five different mtDNA Hinf I haplotypes have been found (I, II, III, IV, V) in dolphins from sites throughout the Gulf of Mexico and along the Atlantic Coast (Fig. 2). The 36 animals sampled in Matagorda Bay area exhibited two of these haplotypes (Table 1); type III $(n=28,77.8 \%)$ and type $V(n=8,22.2 \%)$. 
Nuclear DNA Fingerprinting

Nuclear DNA fingerprinting results are presented in Figs. 3-8. Autoradiographs, three for fingerprints produced with Hind I and three for fingerprints produced with Alu I, are shown with the corresponding similarity index matrix generated by pair-wise comparisons of all the animals on that gel. The Band Scoring sheets are given in Appendix 4. The enzyme, Hinf I, produced an average of 21.18 bands per animal (range, 15-28) while Alu I had an average of 9.72 bands (range, 6-13). Pair-wise comparisons between gel runs could not be made because of the nature of electrophoretic current variation from one run to the next.

\section{Hemoglobin}

All but one of the thirty six animals from Matagorda Bay had a single fast electrophorectic hemoglobin profile, typical of inshore dolphins in the Gulf of Mexico (Duffield 1990; Duffield \& ChamberlinLea 1990; Hersh \& Duffield 1990) The hemoglobin profile of animal 512 (Fig. 9) was characteristic of the pattern exhibited by crosses between animals of coastal and offshore hemoglobin profiles, reflecting an intrusion of offshore alleles into this population. 


\section{DISCUSSION}

\section{Summary of Matagorda Community}

A summary of the on-going behavioral study of bottlenose dolphins in the Matagorda Bay area provides a useful framework from which to discuss the genetic data. Population size in this area was estimated at 700 individual animals with an average group size of $3.5 \pm$ 2.86 (Wursig \& Lynn 1996). Two distinct core use areas between 20-50 $\mathrm{km}$ in diameter were recognized, consistent with previous findings by Shane (1977) and Gruber (1989). There was an increase in numbers of animals in the fall versus the summer but no strong seasonal or diurnal shifts in the overall population were noted (Maze et al. 1997). No movement of dolphins into the open waters of the Gulf of Mexico was observed. Ten of the 1992 freeze-branded animals caught in the extreme NE section of the study area were never resighted in the subsequent behavioral study. Because of the periodic observation of identified dolphins from Matagorda Bay in other neighboring areas along the Texas coast (one animal moved as far as San Antonio Bay, Fig. 1), and because subsequently a low degree of individual association was found over time among the freeze branded animals, the Texas researchers proposed a high degree of group fluidity for dolphins in the Matagorda Bay community (Wursig \& Lynn 1996). 
Capture group composition also provided some insight into social structure. Of the 36 animals sampled the sex ratio was 16 females (44\%) to 20 males $(56 \%)$. Out of the twelve capture groups with two or more animals, the average group size was 2.8 (range 2-5). Groups consisted of subadult males $(n=3)$ or females $(n=1)$, adult males $(n=1)$, presumed mother and calf pairs $(n=2)$, and mixed female groups (Table 2). Four animals were alone when captured. This group composition seemed to follow trends seen in the much more extensively studied resident Sarasota community (Wells et al. 1987), where the animals were found singly or in small groups which changed associations over time. These groups consisted of subadult males and/or females, plus mixed adult female groups (with or without calves) occasionally accompanied by males.

To add genetic analysis to the behavioral observation data for the Matagorda Bay area, I examined the relative degree of relatedness among and between various subgroupings of this population sample.

\section{Males vs Females}

Means of pairwise similarity indices were determined for the overall sample based on nuclear DNA fingerprinting data and then compared for males vs. females using both restriction enzymes (Tables $3 \& 4$ ). Mean SI's for the total population (Alu $I=52.8$, Hinf $I=73.7$ ) were not 
significantly different from the mean of the females (Alu I $=52.0, p=0.8$;

Hinf $\mathrm{I}=71.7, \mathrm{p}=0.1$ ) and the mean of the males (Alu $\mathrm{I}=52.4, \mathrm{p}=0.9$;

Hinf $\mathrm{I}=74.2, \mathrm{p}=0.7$ ). The distrubution of SI's for males compared to females is illustrated in Fig.10. There were no apparent subdivisions within the Matagorda Bay community with regard to sex.

\section{Mothers and Calves}

At the time of capture, the tight affiliation between calves and lactating females led the research team to categorize five pairs of animals as mother-calf pairs. All presumed mother-calf pairs had matching mitochondrial DNA haplotypes. The pairwise SI's for these presumed mother-calf combinations (Table 3 ) ranged from $40.0 \%$ to $88.0 \%$ for Alu I and from $70.0 \%$ to $85.7 \%$ for Hinf I. The distributions of these values compared to the distribution of all SI's are illustrated in Fig. 11. The degree of band-sharing between these pairs covered a wide range of values; none were equivalent to the highest SI's seen in the population. In a study using DNA fingerprinting to examine SI's among captive Asian elephants (Bischof \& Duffield 1994), the highest similarity scores were always parent-offspring or full sibs, although some of the parentoffspring SI values were lower and overlapped in the distribution with unrelated SI values. 
A separate study on the chromosome variants among the 36 Matagorda Bay dolphins (Gunter 1997) directly excluded four of the presumed mother-calf pairs based on the lack of maternal chromosome markers (heteromorphisms) in the calves. Maternal-calf chromosome markers were consistent for one presumed pair (507/509). However, it is unlikely that these two animals were actually mother and calf based on both low SI values (Alu I $=54.0 \%$, Hinf $\mathrm{I}=71.8 \%$; see Table 3 ), and on age estimates ( $507=4-6$ years of age, $509=3$ years of age). Female 507 must have become pregnant when she was still a calf, 1-3 years old. Bottlenose dolphin females have been known in captivity to become pregnant as early as 4-5 years of age (Duffield \& Shell 1994). However, in the wild, first pregnancy has been observed to occur from 6-8 years of age (Wells et al. 1987).

Speculation as to the true nature of the observed associations points to a few possibilities. These include "babysitting" behavior by adult or subadult females other than the mothers, independent excursions by the calves away from their mothers, and incorrect age estimates at the original time of capture. In the Sarasota Bay community, Wells et al. (1987) reported a mean age at separation of 3.5 years $(S D=0.41)$ for four calves and stated that three years seemed to be the minimum age of separation. Given this finding and the fact that four of the five calves were reported to be two years of age or older, an 
underestimate of calf ages by one year could explain the disparity between observational and genetic data. It has also been suggested that due to the extensive die-off of dolphins in the Matagorda Bay population, a number of calves might have been orphaned and formed subsequent associations with unrelated individuals or with half sibs. This would fit with the observation of lower SI's among the presumed mother-calf pairs seen in this study.

\section{MtDNA Haplotypes}

The mtDNA haplotyping suggested a possible division in the sampled animals. The two mt DNA haplotypes present, type III $(n=28)$ and type $\mathrm{V}(\mathrm{n}=8)$, were used as the basis for comparative analysis of SI's. Mean SI's for the type III dolphins (Table 3; Alu I = 49.7, Hinf I = 71.9) were different from the means of the type $\mathrm{V}$ animals (Alu I $=61.2$, Hinf $I=80.2)$. This difference was statistically significant (Alu I, $p=0.005$; Hinf $I, p=0.0001$ ). The distrubution of SI's for type III compared to type $\mathrm{V}$ animals is illustrated in Fig.12.

The presence of two distinct mtDNA haplotypes might be indicative in the population of an historical immigration of two distinct maternal lineages at some point in the establishment of a resident community. With random mating in this community over time, however, the distribution of SI's among the two mtDNA types would be 
expected to have become the same. This led me to ask whether or not the two haplotype groups were distinguishable in any other way.

Upon examination of the observational data, it became evident that the division seen with respect to mt DNA haplotypes was closely connected to an observed behavioral partitioning of these animals. A group of ten animals, 523-532, sampled over a two day time period in the extreme northeast region of the study area were never resighted. Seven of these ten had the type $\mathrm{V}$ haplotype. Furthermore, with the exception of one type $\mathrm{V}$ animal (also not sighted again), these seven accounted for all animals of this particular haplotype sampled. Upon a comparison of SI's between this group of ten animals (not resighted) and the "resident" population sample (all type III and resighted consistently throughout the study), the differences in means and distributions seen with the mtDNA haplotypes became even more pronounced. Mean SI's for the group of ten dolphins were Alu I $=61.1$, Hinf $\mathrm{I}=79.9$ compared with the means of the resident group of animals, Alu $I=49.7$, Hinf $I=71.4$. This difference was statistically significant (Alu I, p $<0.0001$; Hinf I, p $<$ 0.0001). The distribution of the group of ten (not resighted) $v s$. the "residents" is illustrated in Fig.13.

The mean similarity index values for these two subgroups, "ten" and "residents" (see Table 3), and the pair-wise distributions (Fig. 13) indicated that the group of ten animals exhibited a higher degree of 
similarity and were a more genetically homogeneous subgroup than the resident animals. This is interesting in light of genetic observations on the Sarasota Bay resident community. Biochemical genetic studies on the Sarasota community indicated that they were a highly heterozygous population and that samples from outside this resident area were in contrast, highly homozygous (Duffield \& Wells 1986). It was proposed that higher homozygosity in this case was a characteristic of bottlenose dolphin groups which migrated past the Sarasota area. It was further hypothesized that the large amount of heterozygosity in the resident community was, in part, due to reproductive exchange from the migrant groups. Evidence corroborating this potential type of population structure and separation can be found in the literature related to the degree of philopatry in bottlenose dolphin societies.

\section{Philopatry}

Between bottlenose dolphin populations around the world there appears to be considerable variation in the degree of philopatry displayed by inshore dolphins. A review of studies which have documented home range patterns in bottlenose dolphins at various locations, describes many different types (Shane et al. 1986). These include seasonal, periodic and longterm residency patterns as well as the combination of long-range movements and repeated local residency 
(Mead 1975; Connor \& Smolker 1985; Wells et al. 1987; Mead \& Potter 1990; Scott et al. 1990; Wursig \& Harris 1990; Wursig 1994).

Within the Gulf of Mexico, observed home range patterns of inshore animals include both long-term and seasonal residency (Shane et al. 1986). While there is long-term residency of certain well known groups of animals, such as the Sarasota bottlenose dolphin community, evidence exists for more transitional areas within the Gulf of Mexico. For example, a capture release study in the Mississippi Sound (Duffield et al. 1987), using protein electrophoresis to study regional genetic varaiability, showed that samples taken on two consecutive days revealed a complete exchange of genetic profiles, suggesting different populations were "passing through" this area. One of these population types exhibited a high degree of heterozygosity and one was highly homozygous, similar to the genetic differences seen between the Sarasota resident population and coastal (possibly migrant) groups. These data suggest, therefore, that in addition to the local, resident communities there is the presence in the Gulf of Mexico of more transitory groups of animals as well, and that the two population types can be genetically distinguished. 
Feeding Behavior

One question which arises from this issue of philopatry, home range and seasonal migration patterns pertains to the underlying mechanisms responsible for potentially dividing dolphins into resident versus migratory groups. One critical factor responsible for this division can be found in differences in foraging behavior. Feeding behavior for inshore and more offshore or inshore-migratory animals as described by Shane (1990) and others, indicates that cooperative feeding is a common practice among offshore groups of dolphins in deep, open waters off Argentina, South Africa and in the Gulf of Mexico (Saayman et al . 1972; Wursig \& Wursig 1979; Wells et al . 1980; Irvine et al . 1981). Closer to shore in these same areas, inshore animals, often known to be resident communities, were described as feeding independently or in small groups. If we assume that young animals are learning a particular set of feeding behaviors predominantly from their mothers, it would follow that they retain and utilize these behaviors into and throughout adulthood. It would then follow that animals which are raised within inshore groups remain inshore due, in part, to an increase in foraging success gained by familiarity with habitat and prey selection. Likewise, the group foraging advantage would be preserved by offshore, or inshore-migratory, individuals which feed cooperatively and remain within a larger, group structure. 
Evidence for Gene Flow Between the Groups

Though the resident and migratory animals are behaving in ways which keep them seperated ecologically and socially, evidence exists which suggests a signigicant degree of gene flow can occur between the two groups. In the Sarasota resident community, the gene flow rate has been estimated to be as high as $40 \%$ based on paternity analysis of the calves (Duffield \& Wells 1997 a). It was hypothesized that this gene flow was the result of reproductive exchanges with neighboring resident communities as well with migrant groups.

In Matagorda Bay, there were two examples of direct gene flow. One animal, 512, who was part of the "resident" group had a mixed hemoglobin profile (65\% fast : $35 \%$ slow) characteristic of crosses between inshore and offshore animals (Duffield \& Chamberlin-Lea 1990). The presence in this same animal of albumin typical of the inshore type (not the mixed albumin profile of a first generation cross between an offshore and an onshore parent), suggests that the genetic exchange which intruded the offshore hemoglobin type happened at some point in the past.

A distinct chromosomal marker, found previously only in animals in the Sarasota resident community (Duffield \& Wells 1991), was discovered in one animal in the Matagorda Bay study (Gunter 1997). This male, 534, was resighted only once and then not seen again in the 
subsequent field study. Although this marker could have arisen independently, by mutation, within the Matagorda Bay population, the presence of a transient animal with the marker could also indicate a potential for gene flow between communities. The fact that this animal was not resighted suggests it may not share philopatry with the resident community. Whether the animal may have come from a neighboring community where this chromosome marker is present, a migratory group in this area of the Gulf or directly from Sarasota is not known at this time.

\section{Home Range and Migration Distances}

Home range is defined as any area regularly used by an individual or group in the course of performing normal daily activities (Burt 1943; Jewell 1966). In Florida, the resident community in Sarasota occupies an area of approximately $85 \mathrm{~km}^{2}$ (Shane et al . 1986). Two different subsets of animals within this community, mothers with calves and subadult males, occupy home ranges of around $40 \mathrm{~km}^{2}$ while subadult females and adults of both sexes utilize less space, $15-20 \mathrm{~km}^{2}$, on average. Multiple observations of bottlenose dolphins covering distances between $100-600 \mathrm{~km}$ over periods of up to 18 months have been recorded from field studies at various locations throughout the world (Wursig \& Wursig 1977, 1979; Lockyer 1978; Shane 1980; Jones 1991). There is one 
report of a group of identifiable animals off southern California making a roundtrip totaling $1,500 \mathrm{~km}$ in distance along the coast of California (Wells et al . 1983).

In Texas, a home range of $312 \mathrm{~km}^{2}$ was proposed for the Matagorda Bay population (Maze et al . 1997). When ten of the thirty-six freeze branded dolphins were tracked using radio-telemetry from 9 July to 13 September 1992 , a mean range size of $140 \mathrm{~km}^{2}(\mathrm{SD}=90.7)$ was recorded. Though range sizes were similar for males and females, males were reported to visit the extremities of their ranges more often and for longer periods. The longest range of movement for any individual dolphin in the study was $100 \mathrm{~km}$.

It is possible to estimate distances between the different known communities of Tursiops. Approximately $200 \mathrm{~km}$ to the northeast of Matagorda Bay is Galveston Bay. Population estimates of 200 dolphins have been published for the "resident" community in that bay (Brager et al. 1994), while Corpus Christi Bay, located roughly $160 \mathrm{~km}$ to the southwest of Matagorda, has been estimated to contain a resident community of 109 individuals (Scott et al. 1990). Based on migration distances cited in the literature, it would appear reasonable to assume resident dolphins from each of these three communities are capable of interacting, both socially and reproductively, with neighboring communities. This type of gene flow has been described in population 
biology as a "stepping-stone" model (Futuyama 1986). Such a model is useful for developing an overall picture of how these local groups or 'demes' are interacting on an infrequent yet genetically significant level (Minkoff 1983). Overlapping this, there may also be potential for reproductive exchange between seasonal/offshore migratory groups and the resident populations, as well as long ranges of juvenile dispersal. These models have yet to be tested for dolphin communities and migrating groups within the Gulf of Mexico.

\section{Mitochondrial DNA Dispersal Patterns in the Gulf of Mexico}

During the time of working on the Matagorda Bay population, I completed mtDNA Hinf I haplotype analyses on animals from other sites in the Gulf of Mexico and along the Atlantic seaboard of the eastern U.S. This work has shown four geographic distributional patterns for dolphins within this range (Fig. 14).

1. Hinf I haplotype III was found in all coastal samplings in the Gulf of Mexico and on the Atlantic coastal side of Florida to the Indian River Intracoastal Waterway, but was not present in the North Carolina sampling. The distribution of this one type throughout the Gulf of Mexico fits with my conclusion on gene flow in the Matagorda Bay area, the observation of gene flow in the resident Sarasota community and the conclusion of Dowling and Brown (1993) in a previous study of 
mtDNA haplotype distribution in the Gulf of Mexico. However, its distribution on the Atlantic coast of Florida samples modifies Dowling and Brown's conclusion that the Atlantic and Gulf populations were disjunct.

2. Hinf I haplotype $\mathrm{V}$ was found only in the Texas and Mississippi samples, not in the eastern part of the Gulf of Mexico, while Hinf I haplotypes I and II were found only in samples from the east and west coasts of Florida and not in the western part of the Gulf of Mexico.

These disjunct distributions suggested that there was some subdivision of dolphin populations within the Gulf of Mexico (as discussed below).

3. Hinf I haplotypes I, II, and III were distributed in a clinal fashion from the Panhandle region of the west coast of Florida around the Florida Keys to the Indian River Intracoastal Waterway (Atlantic) which suggested gene flow between local populations throughout this region, separate from the western Gulf of Mexico.

4. Hinf I haplotype IV was the only haplotype found in all the North Carolina sample. Its extension into the population area of the Indian River, Florida was substantial $(70 \%)$ and suggested that there was extensive population overlap or exchange in this part of the bottlenose dolphin range along the Atlantic coast. One animal sampled from Tampa Bay on the Gulf side of Florida also had haplotype IV. 
Based on the distribution of these mtDNA haplotypes, we suggest that there are at least three major regions of mitochondrial gene flow within this overall geographic area. One region seems to extend through the western portion of the Gulf of Mexico, past the coasts of Texas and Mississippi. Another is represented by the clinal movement of mtDNA types around the western and eastern coasts of Florida, and the third is a region which includes the Beaufort area of North Carolina, but extends south along the eastern coast of Florida, at least as far as the Indian River.

This subdivision of dolphin populations within the coastal and inshore waters of the Gulf of Mexico may be correlated with oceanographic features such as the Mississippi River influx and/or current patterns which circulate in the Gulf (Fig. 15). For example, there is a major water mass movement north into the Gulf of Mexico from the Caribbean Sea. This water mass splits into two distinct water patterns that circulate along the western and eastern parts of the Gulf. This division seems on an annual basis to move across the Mississippi Sound closest to Louisiana. The current gyre which moves north along the west coast of Florida into the Panhandle region and then south, ultimately converges as a strong water movement around the Florida Keys and north along the east coast of Florida. The Mississippi River and the Gulf current patterns could account for the observed disjunct 
haplotype distributions of coastal dolphins between the western vs. eastern Gulf of Mexico.

These distribution patterns reflect potential movement patterns of dolphins between neighboring population areas, as well as the broader migratory population patterns. Specific geographical regions such as Matagorda Bay may, therefore, represent primary areas of local residence with some interchange between neighboring areas and migratory groups. Furthermore, this explanation predicts that studying both near-shore, as well as local, inshore resident populations throughout the Gulf wherever there are regions of major water movement or shifts in seasonal current patterns or associated oceanographic features will be of use to the future mapping of population subdivision and stock definition within the Gulf of Mexico. 


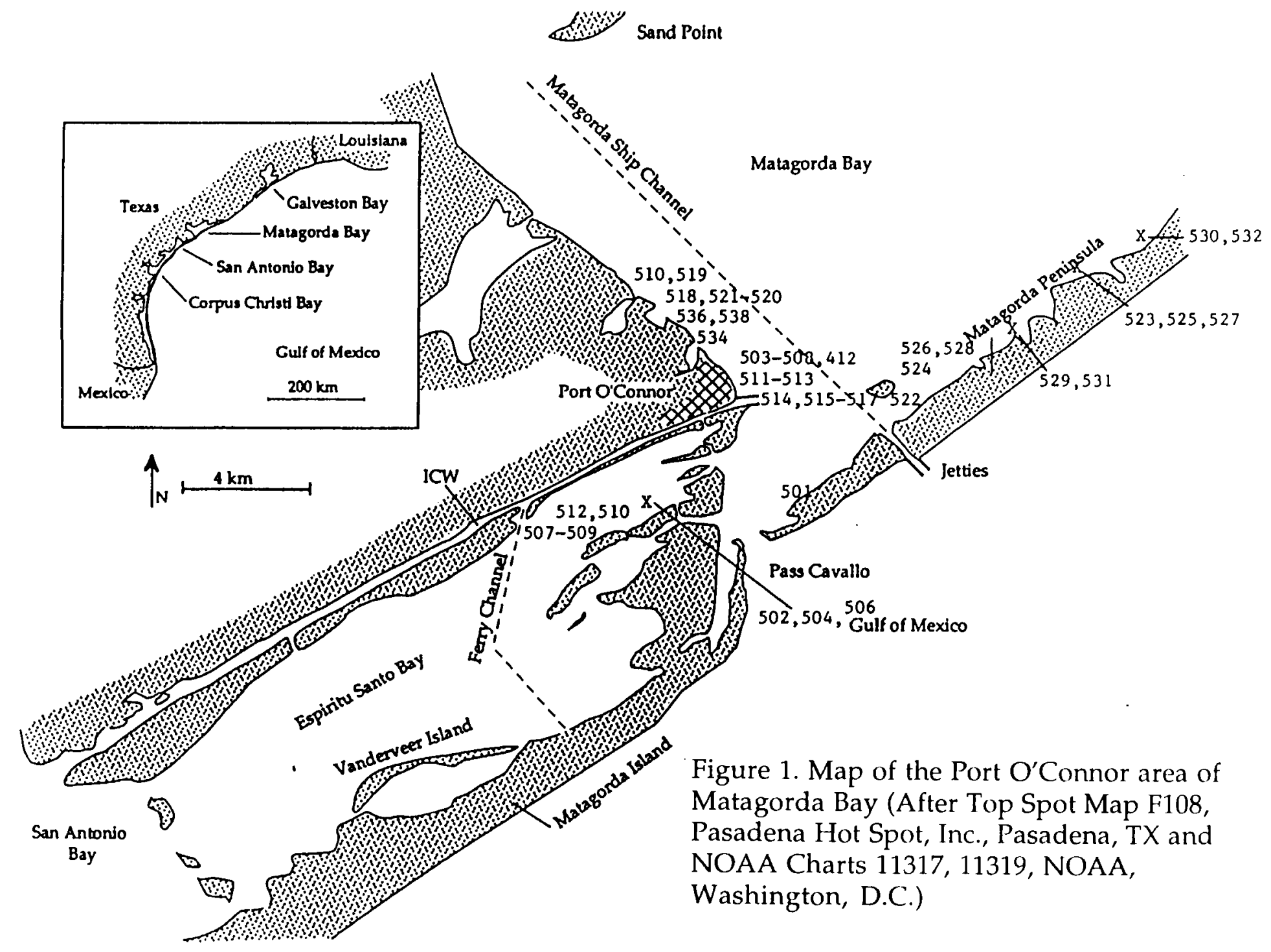



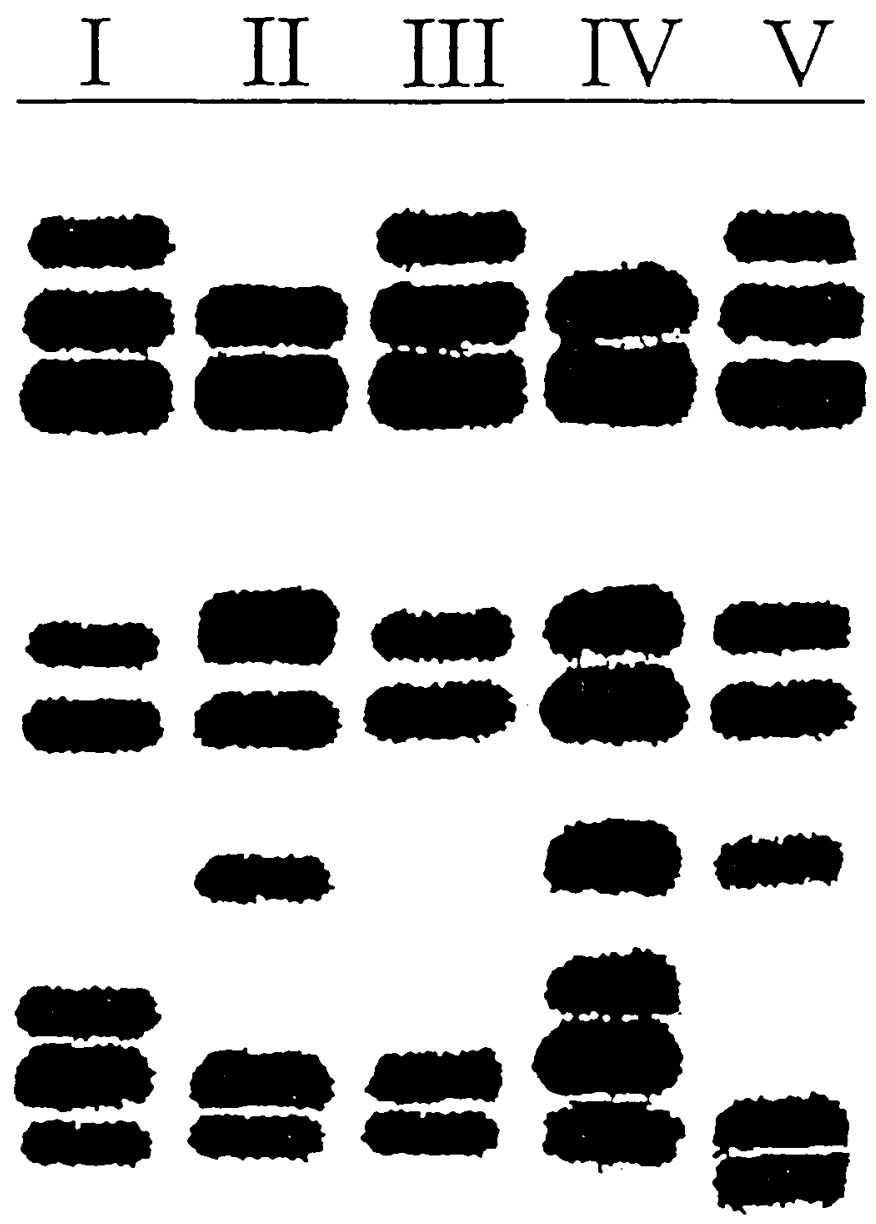

Figure 2. Mitochondrial DNA (mtDNA) Hinf 1 haplotypes I-V in bottle nose dolphins from sites in the Gulf of Mexico and southeastern U.S. Atlantic coast. 


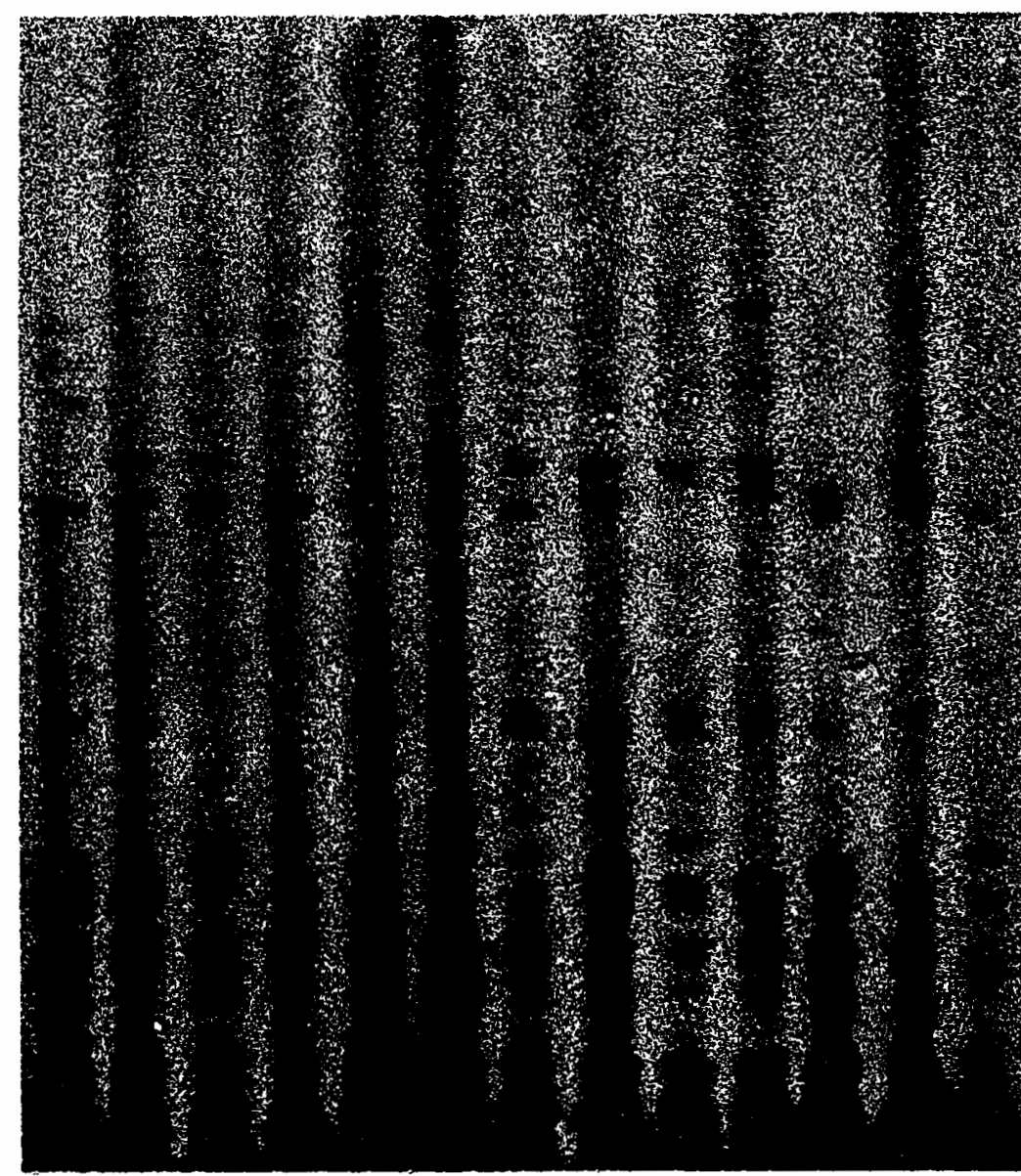

\begin{tabular}{|r|r|r|r|r|r|r|r|r|r|r|r|r|}
\hline $\mathbf{A}$ & $\mathbf{5 0 2}$ & $\mathbf{5 0 3}$ & $\mathbf{5 0 4}$ & $\mathbf{5 0 5}$ & $\mathbf{5 0 6}$ & $\mathbf{5 0 7}$ & $\mathbf{5 0 8}$ & $\mathbf{5 0 9}$ & $\mathbf{5 1 0}$ & $\mathbf{5 1 1}$ & $\mathbf{5 1 2}$ & $\mathbf{5 1 3}$ \\
\hline $\mathbf{5 0 1}$ & 86.5 & 78 & 71.8 & 66.7 & 76.2 & 74.4 & 83.7 & 75 & 61.9 & 70 & 71.1 & 68.2 \\
\hline $\mathbf{5 0 2}$ & & 58.8 & 62.5 & 74.3 & 68.6 & 72.2 & 72.2 & 78.8 & 74.3 & 78.8 & 68.4 & 70.3 \\
\hline $\mathbf{5 0 3}$ & & & 77.8 & 61.5 & 76.9 & 60 & 85 & 70.3 & 56.4 & 70.3 & 66.7 & 63.4 \\
\hline $\mathbf{5 0 4}$ & & & & 64.9 & 75.7 & 63.2 & 68.4 & 62.9 & 59.5 & 62.9 & 65 & 56.4 \\
\hline $\mathbf{5 0 5}$ & & & & & 65 & 68.3 & 63.4 & 73.7 & 55 & 78.9 & 60.5 & 57.1 \\
\hline $\mathbf{5 0 6}$ & & & & & & 73.2 & 73.2 & 73.7 & 55 & 73.7 & 69.8 & 76.2 \\
\hline $\mathbf{5 0 7}$ & & & & & & & 61.9 & 71.8 & 68.3 & 76.9 & 68.2 & 79.1 \\
\hline $\mathbf{5 0 8}$ & & & & & & & & 82.1 & 58.5 & 71.8 & 72.7 & 65.1 \\
\hline $\mathbf{5 0 9}$ & & & & & & & & & 63.2 & 71.8 & 73.2 & 70 \\
\hline $\mathbf{5 1 0}$ & & & & & & & & & & 63.2 & 74.4 & $\mathbf{6 6 . 7}$ \\
\hline $\mathbf{5 1 1}$ & & & & & & & & & & & 68.3 & 70 \\
\hline $\mathbf{5 1 2}$ & & & & & & & & & & & 84.4 \\
\hline
\end{tabular}

Figure 3. Autoradiograph and corresponding similarity index matrix for Hinf I, gel A. 


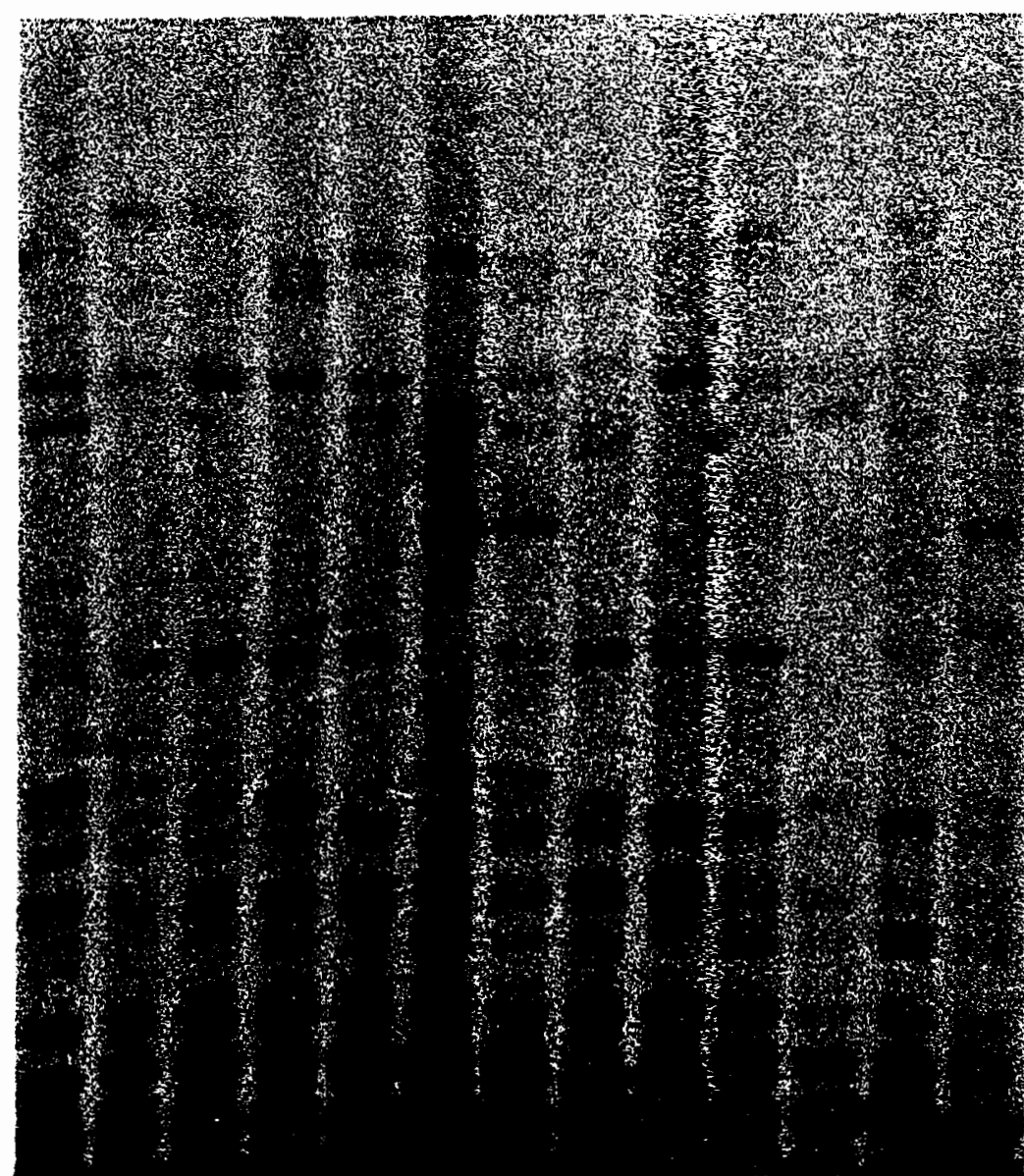

\begin{tabular}{|r|r|r|r|r|r|r|r|r|r|r|r|r|}
\hline $\mathbf{B}$ & $\mathbf{5 1 5}$ & $\mathbf{5 1 6}$ & $\mathbf{5 1 7}$ & $\mathbf{5 1 8}$ & $\mathbf{5 1 9}$ & $\mathbf{5 2 0}$ & $\mathbf{5 2 1}$ & $\mathbf{5 2 2}$ & $\mathbf{5 2 3}$ & $\mathbf{5 2 4}$ & $\mathbf{5 2 5}$ & $\mathbf{5 2 6}$ \\
\hline $\mathbf{5 1 4}$ & 68.2 & $\mathbf{7 8}$ & 79.1 & 68.3 & 77.3 & 82.6 & 69.4 & 80.9 & 72.3 & $\mathbf{7 1 . 1}$ & 68.2 & 76 \\
\hline $\mathbf{5 1 5}$ & & $\mathbf{6 5}$ & 85.7 & 85 & 83.7 & 80 & 62.5 & $\mathbf{7 8}$ & 69.6 & 68.2 & $\mathbf{7 4 . 4}$ & 65.3 \\
\hline $\mathbf{5 1 6}$ & & & 70 & 57.9 & 68.3 & 69.8 & 65.2 & 76.9 & 72.7 & 71.4 & 73.1 & 76.6 \\
\hline $\mathbf{5 1 7}$ & & & & 85 & 79.1 & 80 & 62.5 & 82.9 & 73.9 & 81.8 & 88.4 & 69.4 \\
\hline $\mathbf{5 1 8}$ & & & & & 78 & 74.4 & 56.5 & 76.9 & 68.2 & 71.4 & 78 & 63.8 \\
\hline $\mathbf{5 1 9}$ & & & & & & 82.6 & 65.3 & 71.4 & 63.8 & 62.2 & 68.2 & 68 \\
\hline $\mathbf{5 2 0}$ & & & & & & & 78.4 & 77.3 & 73.5 & 72.3 & 78.3 & 80.8 \\
\hline $\mathbf{5 2 1}$ & & & & & & & & 68.1 & 65.4 & 64 & 65.3 & 76.4 \\
\hline $\mathbf{5 2 2}$ & & & & & & & & & 71.1 & 79.1 & 81 & 70.8 \\
\hline $\mathbf{5 2 3}$ & & & & & & & & & & 83.3 & 76.6 & 71.7 \\
\hline $\mathbf{5 2 4}$ & & & & & & & & & & & 93.3 & 78.4 \\
\hline $\mathbf{5 2 5}$ & & & & & & & & & & & & 84 \\
\hline
\end{tabular}

Figure 4. Autoradiograph and corresponding similarity index matrix for Hinf I, gel B. 


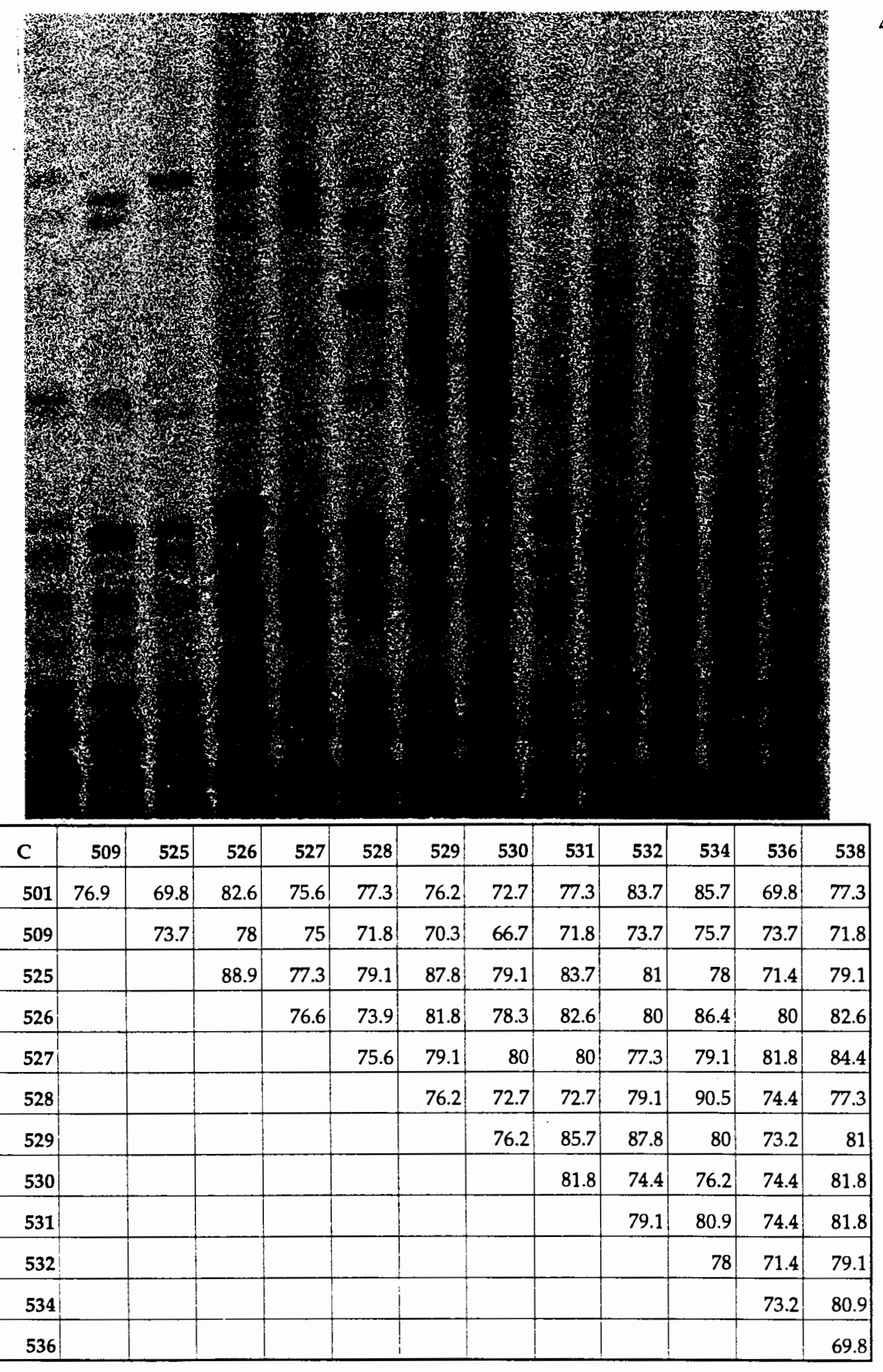




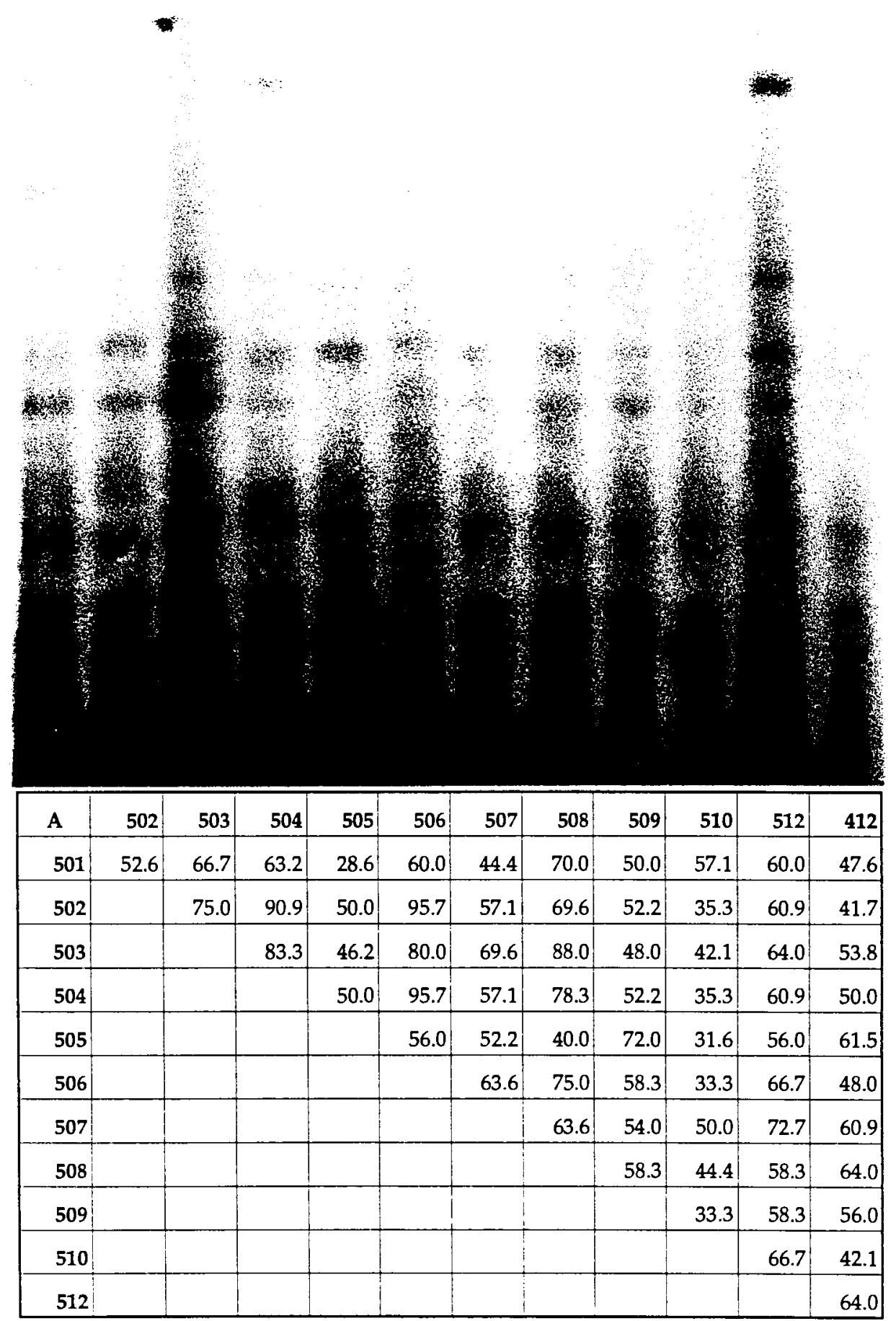

Figure 6. Autoradiograph and corresponding similarity index matrix for Alu I, gel A. 


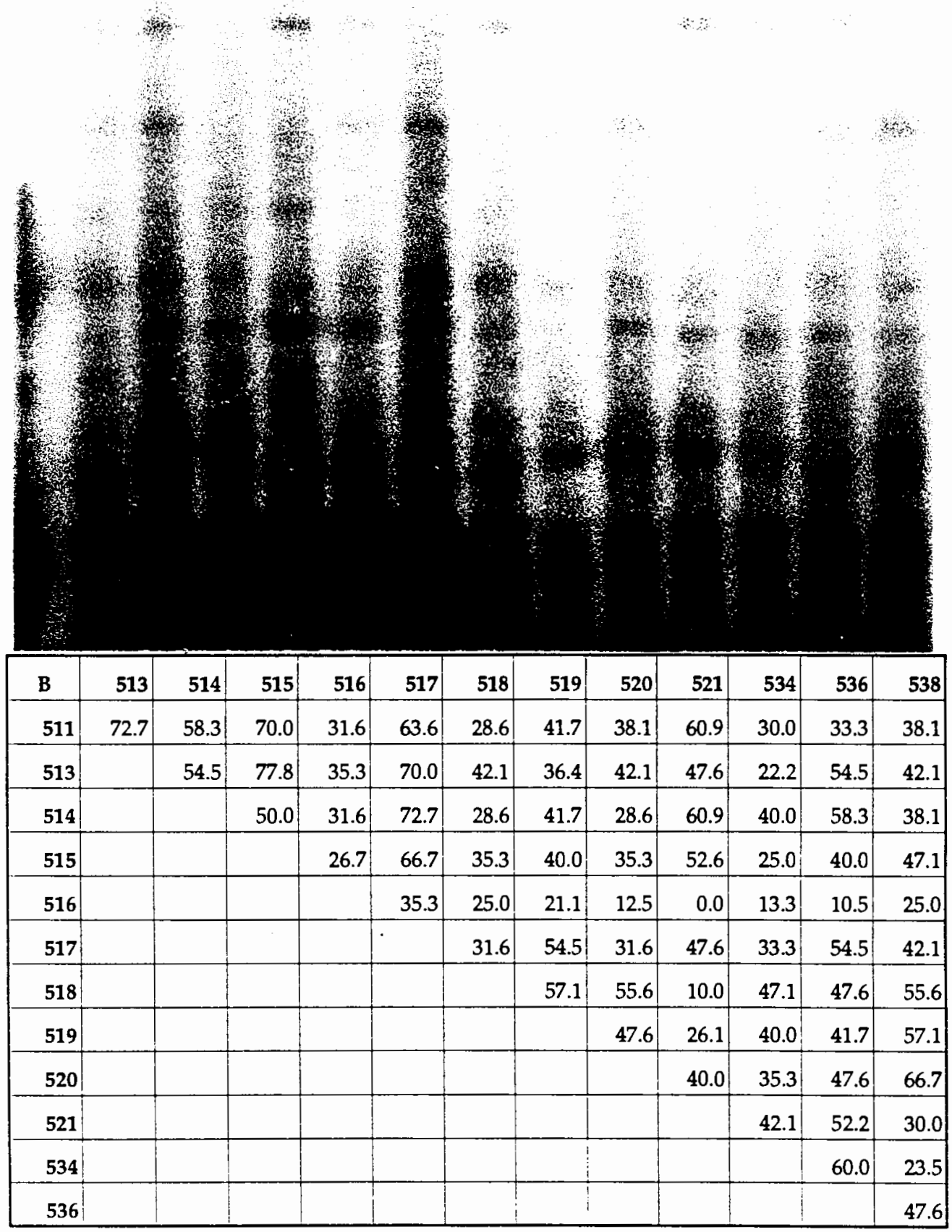

Figure 7. Autoradiograph and corresponding similarity index matrix for Alu I, gel B. 


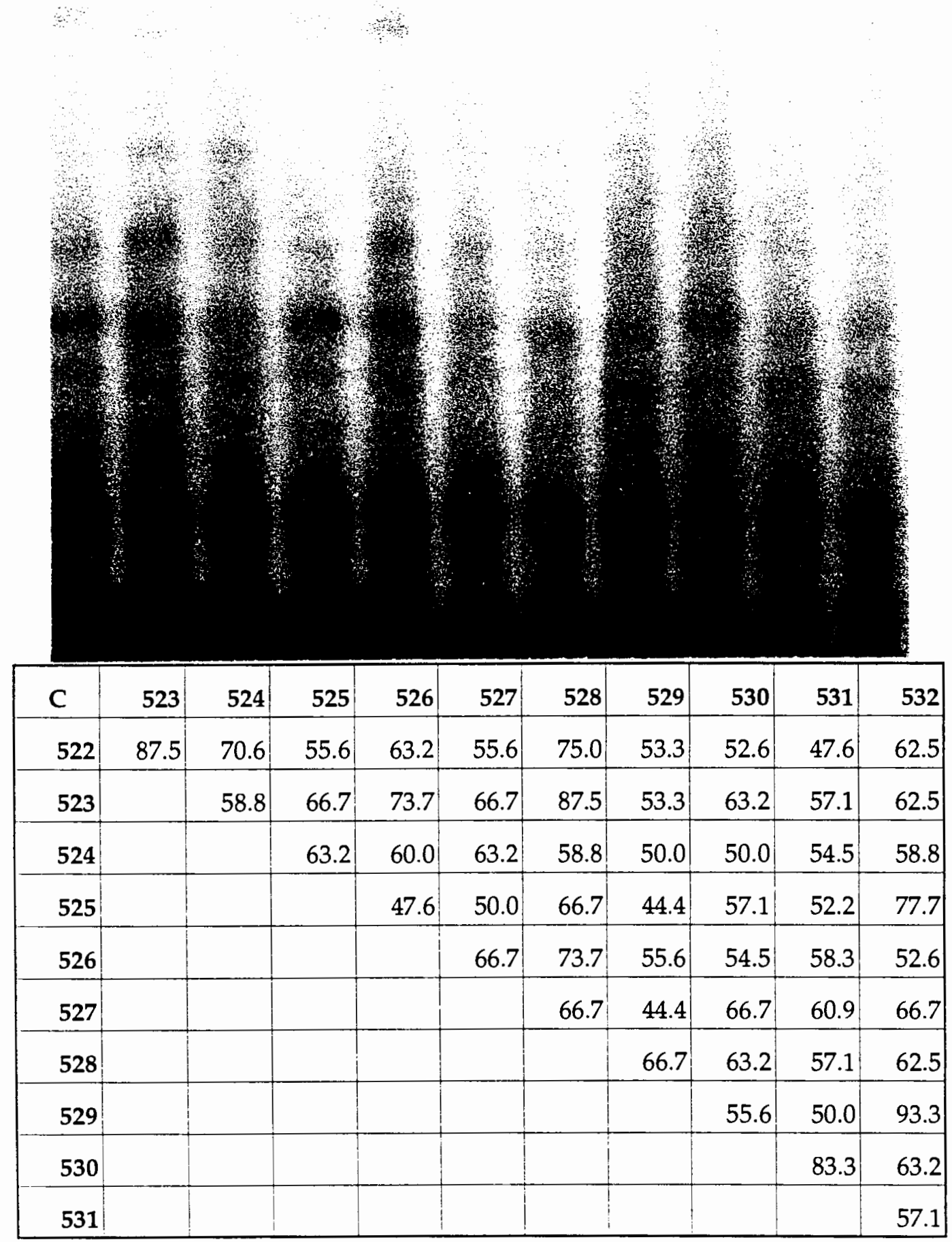

Figure 8. Autoradiograph and corresponding similarity index matrix for Alu I, gel C. 


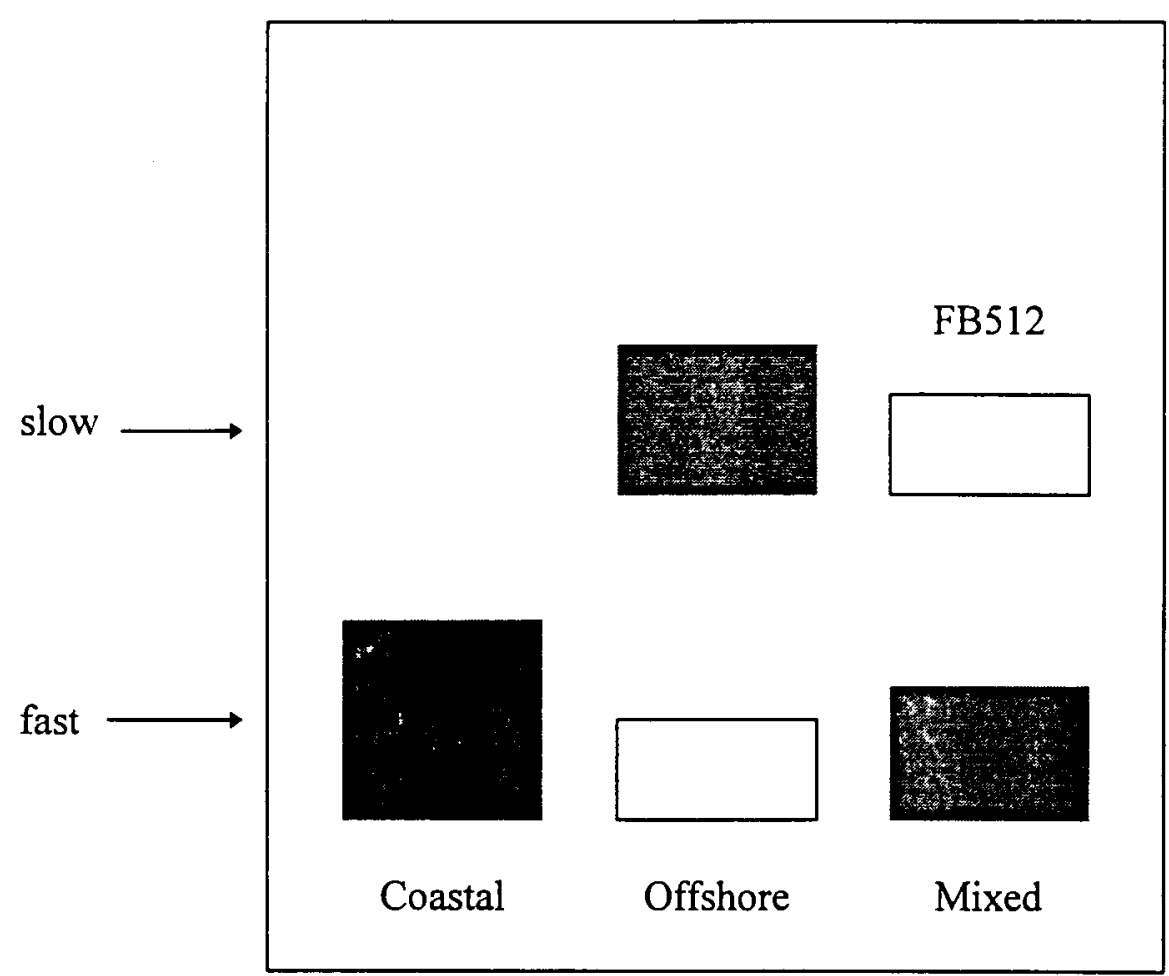

$\begin{array}{lll} & \begin{array}{l}70 \% \\ \text { slow }\end{array} & \begin{array}{l}35 \% \\ \text { slow }\end{array} \\ & & \\ 100 \% & 30 \% & 65 \% \\ \text { fast } & \text { fast } & \text { fast }\end{array}$

Figure 9. Hemoglobin electrophoretic profiles for coastal, offshore, and mixed types (animal FB512) 

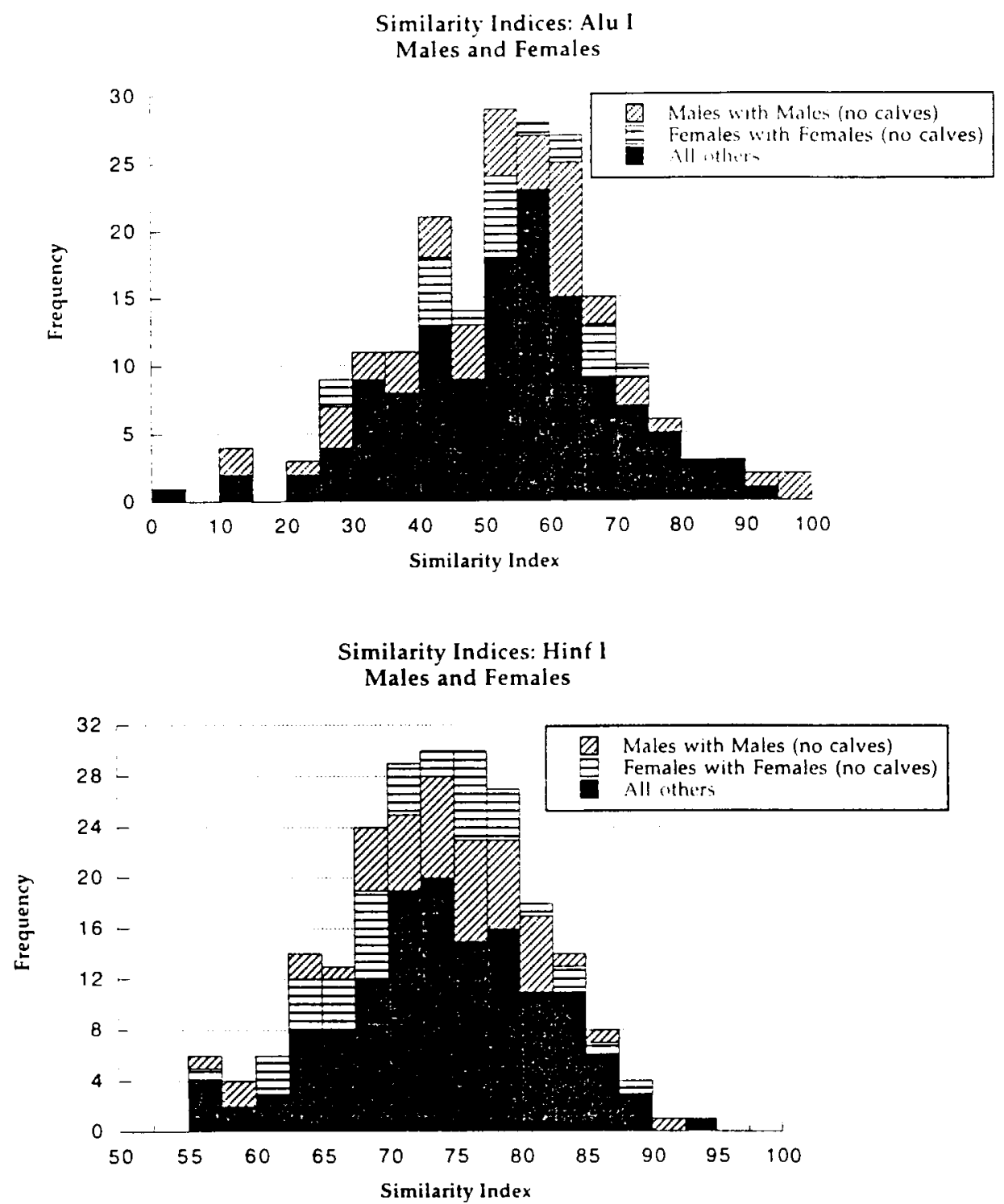

Figure 10. Similarity Index graphs of males with males, females with females and all others. Calves not included with male or female comparisons. 


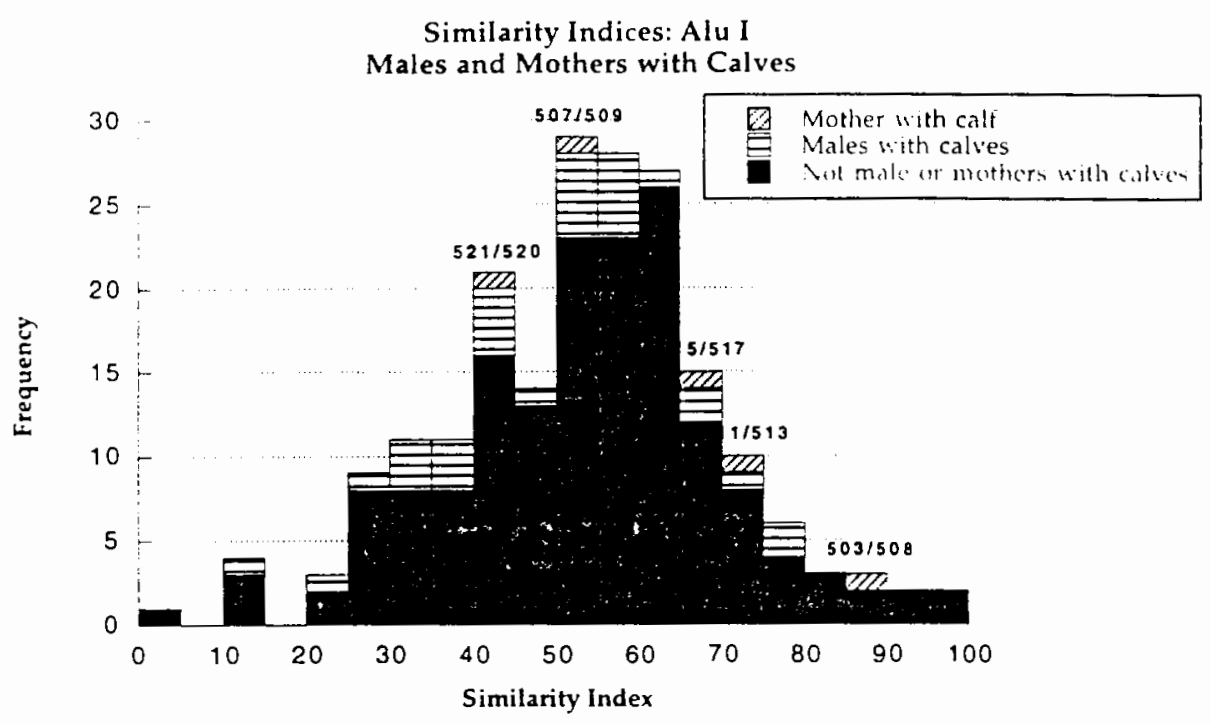

Similarity Indices: Hinf I

Males and Mothers with Calves

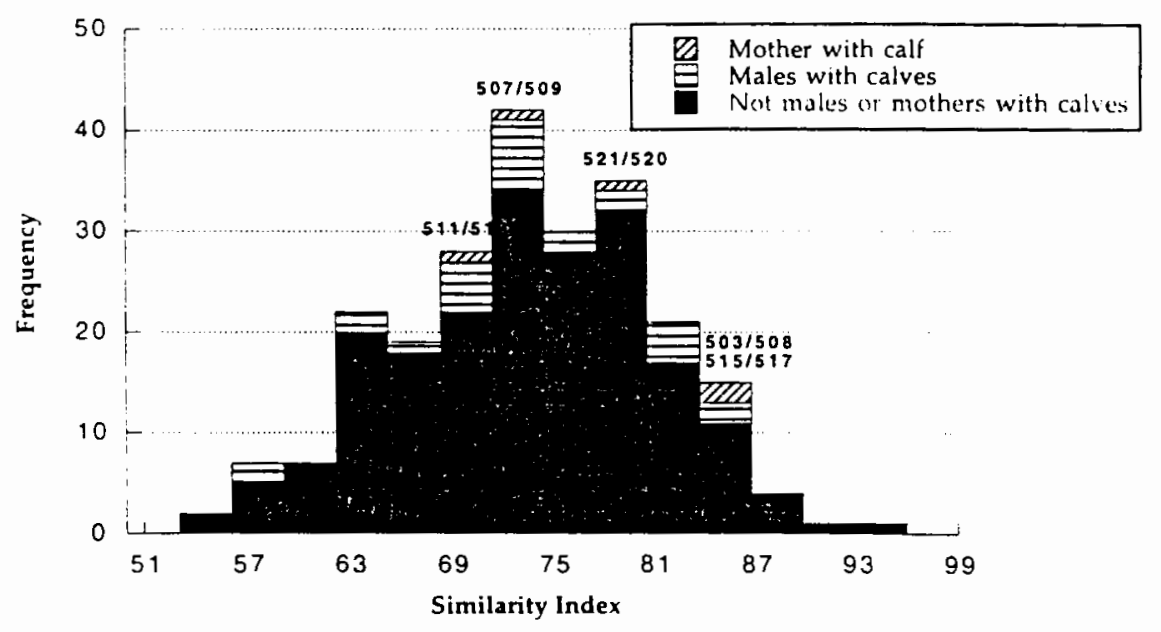

Figure 11. Similarity Index graphs of presumed mother/calf pairs and male/calf pairs. Numbers indicate location of corresponding presumed mother/calf pair. 

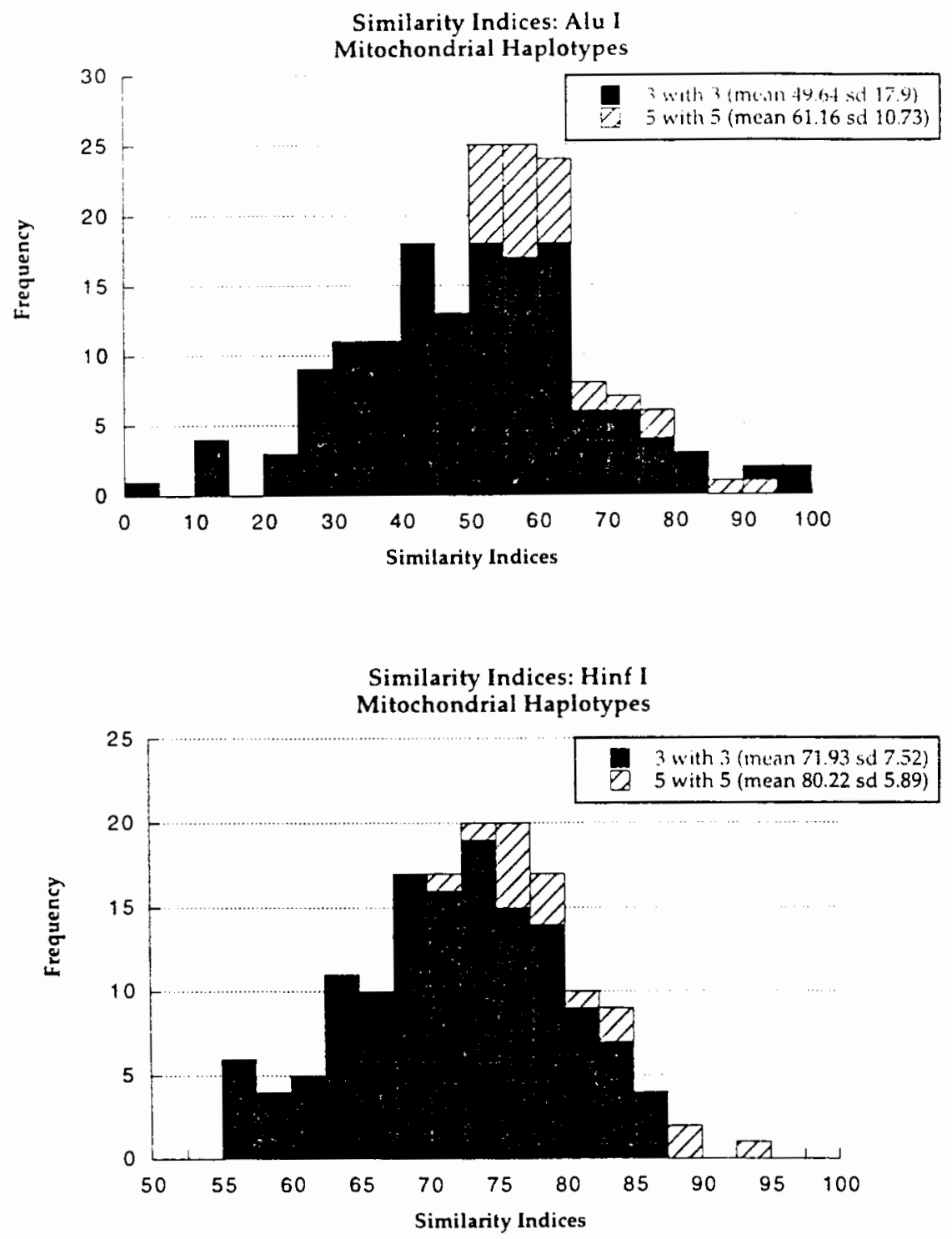

Figure 12. Similarity Index graphs based on mitochondrial haplotypes. 

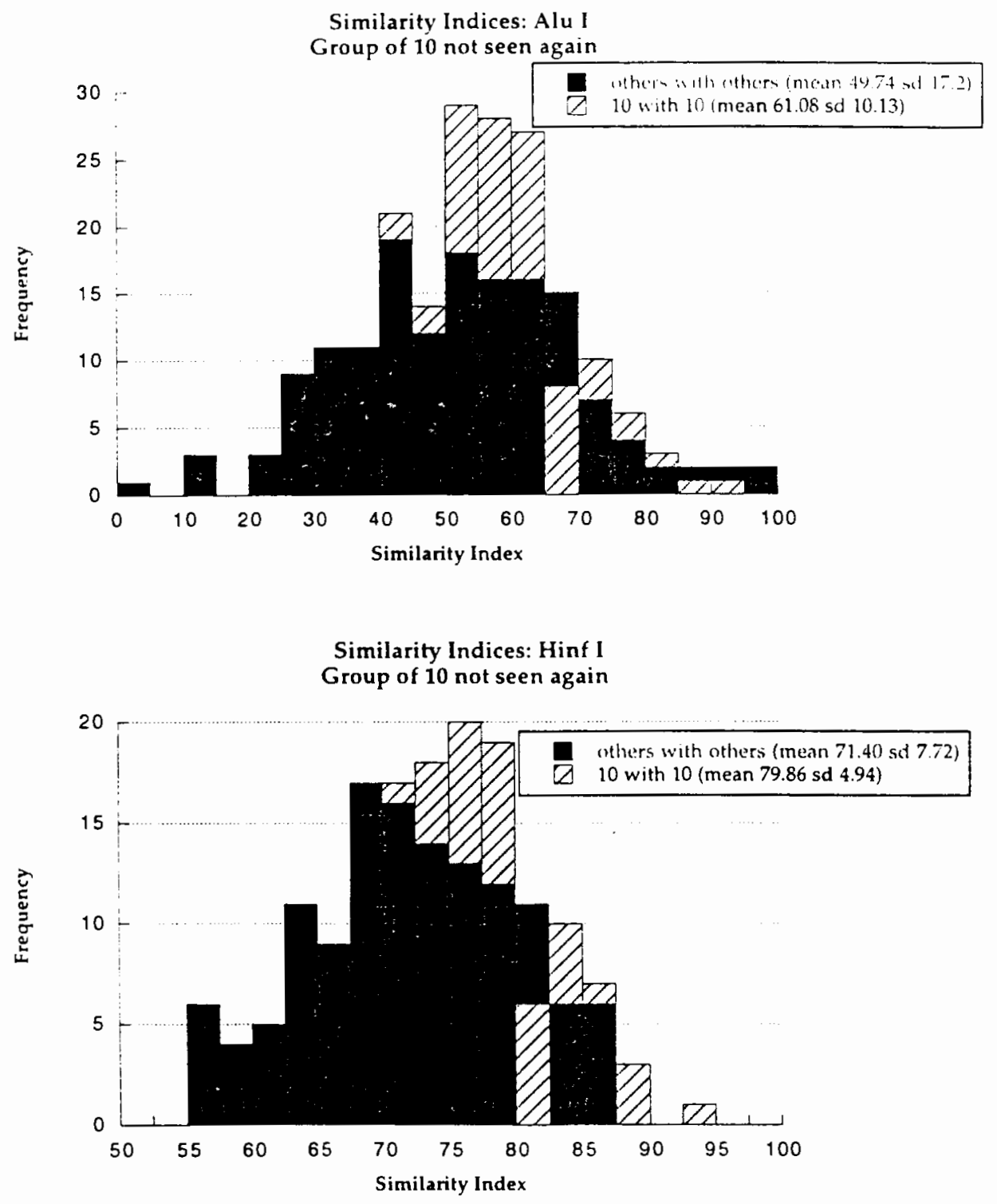

Figure 13. Similarity Index graphs based on observational data. Animals separated into those resighted and group of 10 not resighted. 


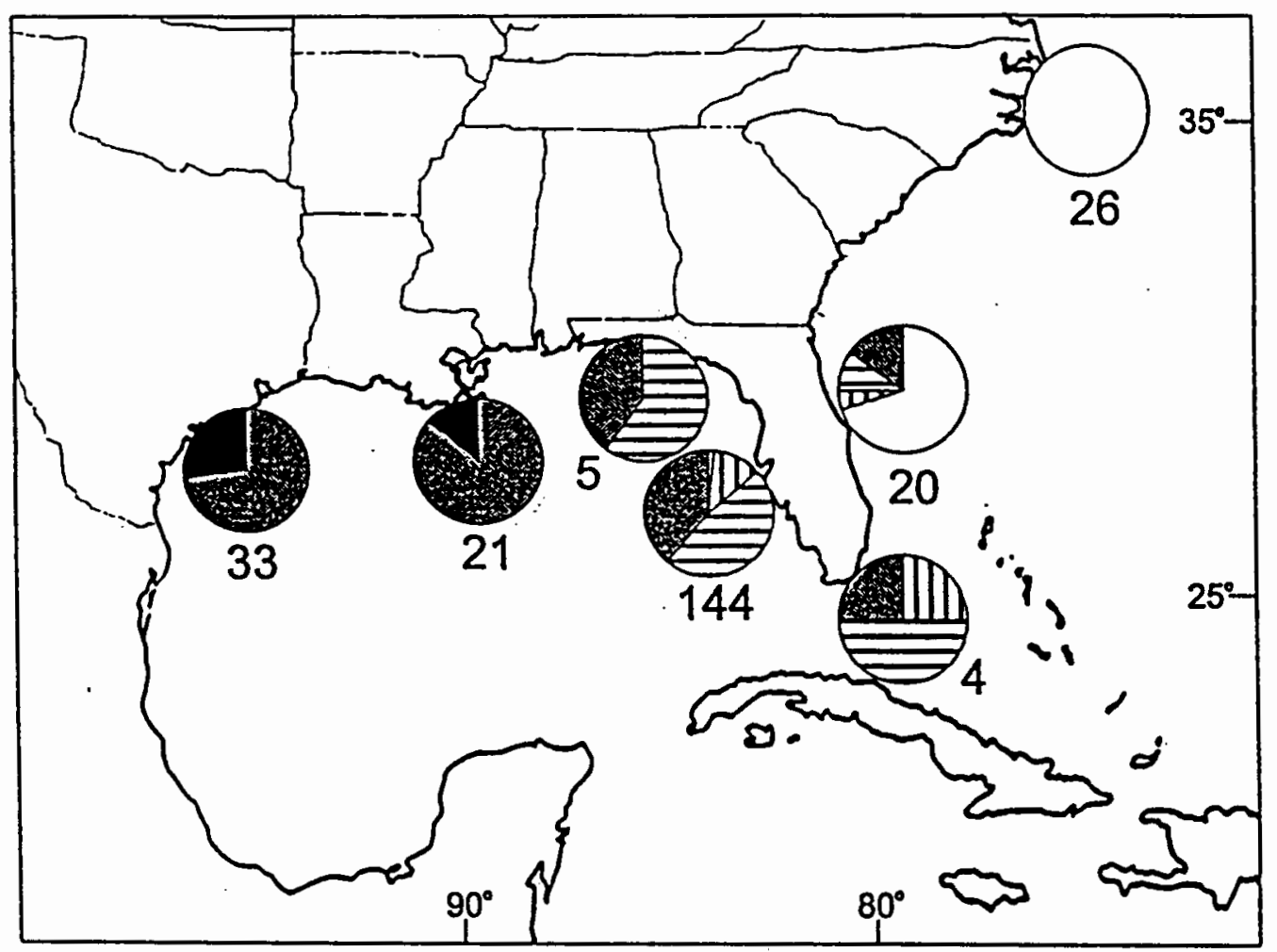

Figure 14. Geographic distribution of mtDNA Hinf I haplotype frequencies. Type $1=$ white, Type II = horizontal hatch, Type III = grey, Type IV = vertical hatch, Type $\mathrm{V}=$ black. 


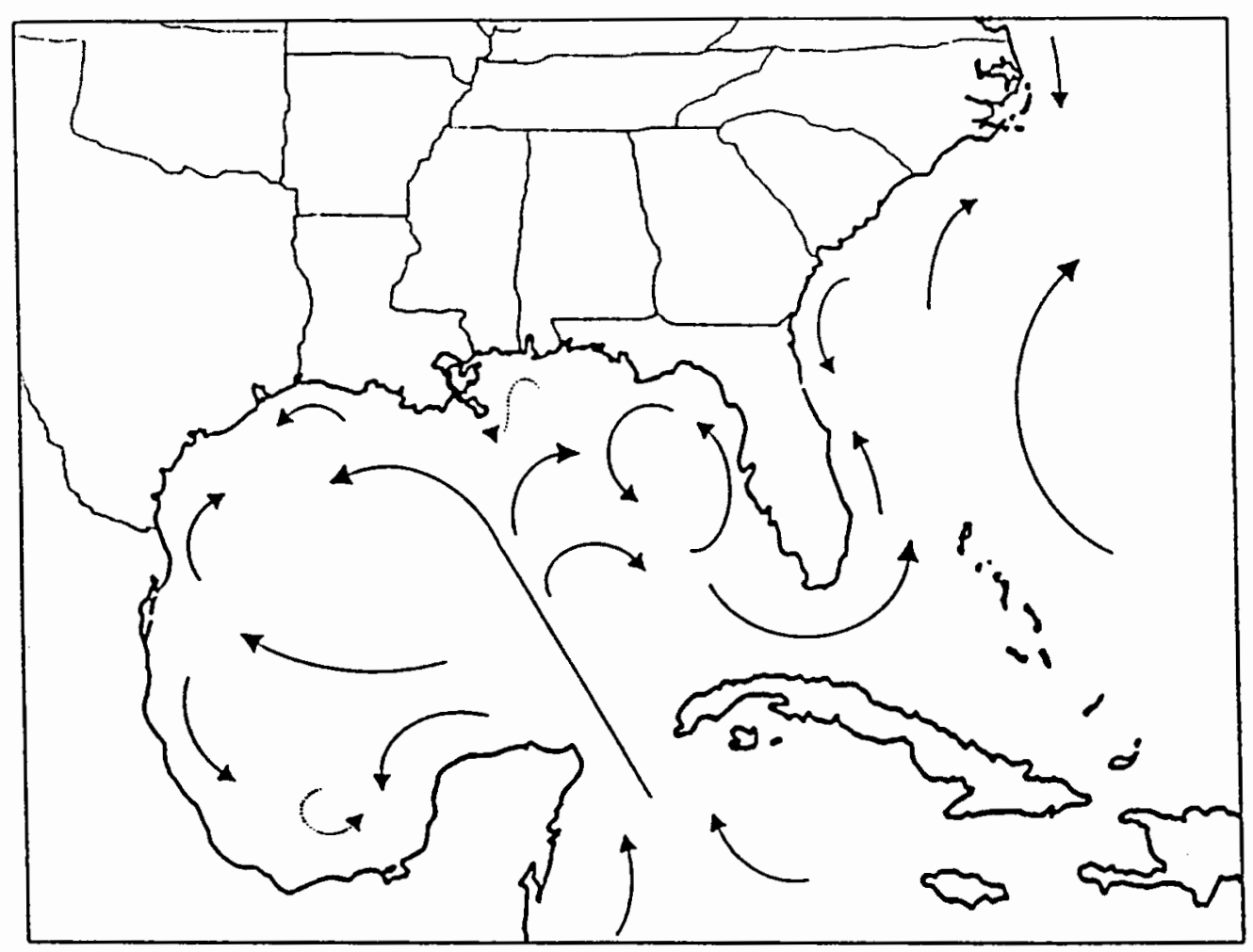

Figure 15. Major water currency pattenrs (Atlas of Pilot Charts, Defense Mapping Agency, NV PUB 106. Ed \#2002. 1994) 


\begin{tabular}{|c|c|c|c|c|}
\hline ID & SEX & AGE & Mt TYPE & COMMENTS \\
\hline 501 & $\bar{F}$ & 12 to 20 & III & tagged $7 / 10 / 92$ \\
\hline 502 & $\mathrm{M}$ & 10 & III & tagged $7 / 9 / 92$ \\
\hline \multirow[t]{3}{*}{503} & $\bar{F}$ & 10 to 12 & III & tagged $7 / 10 / 92$ pregnant \\
\hline & & & & 1st trimester, lactating \\
\hline & & & & Mother of FB 508 \\
\hline 504 & $M$ & 10 to 12 & III & tagged $7 / 9 / 92$ \\
\hline \multirow[t]{2}{*}{505} & $\mathrm{~F}$ & 6 to 8 & III & tagged $7 / 11 / 92$ pregnant \\
\hline & & & & 1st trimester \\
\hline 506 & $\mathrm{M}$ & 8 & III & tagged $7 / 9 / 92$ \\
\hline \multirow[t]{2}{*}{507} & $\mathbf{F}$ & 4 to 6 & III & tagged $7 / 11 / 92$ mother of \\
\hline & & & & FB 509, Pregnant first trimester \\
\hline 508 & $\mathrm{M}$ & 2 & $\overline{\text { III }}$ & tagged $7 / 10 / 92$, calf of FB503 \\
\hline 509 & $F$ & 3 & III & tagged $7 / 11 / 92$, calf ofFB507 \\
\hline 510 & $\mathrm{M}$ & 2 & III & tagged $7 / 11 / 92$ \\
\hline \multirow[t]{2}{*}{511} & $\mathrm{~F}$ & 12 to 20 & III & tagged $7 / 12 / 92$, mother of \\
\hline & & & & FB513 Pregnant, 1st trimester \\
\hline 512 & $\mathrm{M}$ & 4 to 6 & III & tagged $7 / 11 / 92$ Mixed hemoglobin \\
\hline 513 & $\mathrm{~F}$ & 1 & III & tagged $7 / 12 / 93$, calf of FB511 \\
\hline 514 & $\bar{M}$ & 12 & III & tagged $7 / 14 / 92$ \\
\hline 515 & $\mathrm{~F}$ & 8 to 10 & III & tagged $7 / 14 / 92$, mother of FB517, lactating \\
\hline 516 & $M$ & 20 & III & tagged $7 / 14 / 92$ \\
\hline \multirow[t]{5}{*}{517} & $F$ & 2 & III & tagged $7 / 14 / 92$, calf ofFB515. \\
\hline & & & & "51" of left side of fin unreadable. \\
\hline & & & & Dead: TMMSN \\
\hline & & & & ID\# P0249 collected between $9 / 6$ \\
\hline & & & & and $12 / 20 / 92$ \\
\hline 518 & $\bar{M}$ & 8 & III & tagged $7 / 15 / 92$ \\
\hline 519 & $F$ & 8 to 10 & III & tagged $7 / 14 / 92$. Possibly pregnant (early) \\
\hline 520 & $\mathrm{M}$ & 2 & III & tagged $7 / 15 / 92$. Calf of FB521 \\
\hline \multirow[t]{3}{*}{521} & $\mathrm{~F}$ & 6 to 8 & III & tagged $7 / 15 / 92$. Weak crossbar \\
\hline & & & & on "2", left side of fin. Mother of FB520 \\
\hline & & & & Pregnant (1st trimester), lactating \\
\hline 522 & $\mathrm{M}$ & 5 to 7 & III & tagged $7 / 17 / 92$ \\
\hline 523 & $\mathrm{~F}$ & 20 to 40 & $\mathrm{~V}$ & tagged $7 / 17 / 92$ \\
\hline 524 & $\mathrm{M}$ & 5 to 7 & $\mathrm{~V}$ & tagged $7 / 17 / 92$ \\
\hline 525 & $\mathbf{F}$ & 3 to 4 & $\bar{V}$ & tagged $7 / 17 / 92$ \\
\hline \multirow[t]{2}{*}{526} & $\mathrm{M}$ & 6 to 8 & $\mathrm{~V}$ & tagged $7 / 17 / 92$. Middle bar \\
\hline & & & & of "6" poor on left side of fin \\
\hline \multirow[t]{2}{*}{527} & $\mathrm{~F}$ & 6 to 8 & $\mathrm{~V}$ & tagged $7 / 17 / 92$. Pregnant \\
\hline & & & & (1st trimester) lactating \\
\hline 528 & $\mathrm{M}$ & 3 to 5 & $\mathrm{~V}$ & tagged $7 / 17 / 92$ \\
\hline 529 & $\mathrm{~F}$ & 4 & $\mathrm{~V}$ & tagged $7 / 18 / 92$ \\
\hline 530 & $\bar{M}$ & 20 to 40 & III & tagged $7 / 18 / 92$ \\
\hline 531 & $\mathrm{~F}$ & 3 to 4 & III & tagged $7 / 18 / 92$ \\
\hline 532 & $\bar{M}$ & 20 to 40 & III & tagged $7 / 18 / 92$ \\
\hline 534 & $M$ & 4 to 6 & III & tagged $7 / 19 / 92$ chromosome marker \\
\hline 536 & $\mathrm{M}$ & 4 to 6 & III & tagged $7 / 19 / 92$. Brand looks like "535" \\
\hline 538 & $\mathrm{M}$ & 5 to 7 & III & tagged $7 / 19 / 92$ \\
\hline RoTo 412 & $\mathrm{M}$ & 2 & $\mathrm{~V}$ & tagged $7 / 10 / 92$ \\
\hline
\end{tabular}


All Male

$\begin{array}{lll}1 & 502,504,506 & 8-12 \\ 2 & 522,524,526,528 & (3-5) \text { to }(6-8) \\ 3 & 530,532 & 20-40 \\ 4 & 534,536,538 & 4-7\end{array}$

All Female (no calves)

$\begin{array}{lll}1 & 523,525,527 & (3-4)(6-8)(20-40) \\ 2 & 529,531 & 3-4\end{array}$

Presumed Mother and Calf

$\begin{array}{lll}1 & 511,513 & (12-20)(1) \\ 2 & 507,509 & (4-6)(3)\end{array}$

Presumed Mother(s) and Calves plus Male

1

2

3

$503,508,412$

$\mathbf{5 1 8 , 5 2 0 , 5 2 1}$

$507,509,514,515,517$

Adult Male and Female

1

516,519

(20) $(8-10)$

Table 2. Composition of captured groups of dolphins. 


\begin{tabular}{|l|ccc|ccc|}
\hline \multicolumn{1}{|c|}{ Group } & Mean & SD & Range & Mean & SD & Range \\
\hline All SI indices & 52.81 & 16.74 & $0-95.7$ & 73.74 & 7.44 & $55-93.3$ \\
Males & 52.45 & 19.23 & $10.5-95.7$ & 74.19 & 6.92 & $55-90.5$ \\
Females & 52.03 & 12.25 & $26.1-70$ & 71.71 & 7.49 & $57.1-87.8$ \\
Moms with calves & 64.34 & 18.3 & $40-88$ & 78.18 & 7.26 & $70-85.7$ \\
$\begin{array}{l}\text { Females(-moms) } \\
\text { with calves }\end{array}$ & 52.81 & 13.61 & $35.3-77.8$ & 72.4 & 8.07 & $57.1-88.4$ \\
Males with calves & 48.88 & 16.1 & $12.5-78.3$ & 73.19 & 7.57 & $56.4-85$ \\
mtDNA & & & & & & \\
haplotype 3 & 49.64 & 17.9 & $0-95.7$ & 71.93 & 7.52 & $55-86.5$ \\
$\begin{array}{l}\text { mtDNA } \\
\text { haplotype 5 }\end{array}$ & 61.16 & 10.73 & $44.4-87.5$ & 80.22 & 5.89 & $71.7-93.3$ \\
$\begin{array}{l}\text { Group of "10" } \\
\text { All others } \\
\text { besides "10" }\end{array}$ & 61.08 & 10.13 & $44.4-93.3$ & 79.86 & 4.94 & $71.7-93.3$ \\
\hline
\end{tabular}

Table 3. Means of pairwise Similarity Index values (Hinf I and Alu I) for subgroupings of dolphins from the Matagorda Bay sample set. 


\begin{tabular}{|c|c|c|c|c|c|}
\hline Groups Compared & Unpalred atudent t- & Meane & & & \\
\hline & Mean difference & 1 value & P value & $95 \%$ confldence Interval & difference ls... \\
\hline Alu I etetlotlce & & & & of the differance & \\
\hline 3 with 3 vs. 5 with 5 & 11.524 & 2.8684 & 0.0047 & 3.589 to 19.459 & very significam \\
\hline Males with Males (-calves) vs. Moms with calves & 11.891 & 1.317 & 0.1941 & $(-6.2629) 10 \quad 30.045$ & nof significant \\
\hline Males with calves vs. Moms with calves & 15.46 & 1.9541 & 0.05292 & $(0.6358) \quad 10 \quad 31.556$ & not significant \\
\hline Females with calves vs. Moms with calves & 11.533 & 1.511 & 0.1481 & $(-4.5024) 10 \quad 27.569$ & not significant \\
\hline Males with Males (-calves) vs. Females with Females (-calves) & .0 .4171 & 0.0927 & 0.9264 & $(-9.3978) \quad 10 \quad 8.5636$ & not significant \\
\hline Males with calves vs. Females (not moms) with calves & 3.8267 & 0.81 & 0.4224 & $(-5.8497) \quad 10 \quad 13.703$ & not significant \\
\hline 10 's with 10 's vs. others with others & 11.346 & 4.5538 & $<0.0001$ & 6.4319 to 16.259 & extremely elgnificant \\
\hline & & & & & \\
\hline & & & & & \\
\hline Hinf I statistics & & & & & \\
\hline 3 with 3 vs. 5 with 5 & 8.2914 & 4.2555 & 0.0001 & 4.4417 to 12.141 & extremely signilicant \\
\hline Males with Males (-calves) vs. Moms with calves & 3.9881 & 1.2223 & 0.2271 & $(-2.5576)$ to 10.530 & not significant \\
\hline Males with calves vs. Moms with calves & 4.9874 & 1.361 & 0.1837 & $(-2.4964)$ to 12.471 & not significant \\
\hline Females with calves ys. Moms with calves & 5.78 & 1.468 & 0.1546 & $(-2.3285)$ to 13.889 & not significant \\
\hline 10 's with 10 's vs. others with others & -8.4591 & 6.0547 & $<0.0001$ & $(-11.219) 10(-5.6994)$ & extremely sianificant \\
\hline
\end{tabular}

Table 4. Summary of statistical analysis for dolphins sampled in Matagorda Bay 


\begin{tabular}{|cccc|}
\hline Enzyme & Mother/Calf & Similarity Index (\%) & Average SI Value \\
\hline \multirow{2}{*}{ Alu I } & $503 / 508$ & 88.0 & \\
& $511 / 513$ & 73.0 & \\
& $515 / 517$ & 66.7 & \\
& $507 / 509$ & 54.0 & \\
& $521 / 520$ & 40.0 & \\
\hline \multirow{3}{*}{ Hinf I } & $515 / 517$ & 85.7 & \\
& $503 / 508$ & 85.0 & \\
& $521 / 520$ & 78.4 & \\
& $507 / 509$ & 71.8 & \\
& $511 / 513$ & 70 \\
\hline
\end{tabular}

Table 5. Pairwise SI's for presumed mother-calf combinations for Hinf I and Alu I. The overall mean SI values for the population are shown. 


\section{BIBLIOGRAPHY}

AQUADRO, C.F., W.A. NOON AND D.J. BEGUN. 1992. RFLP analysis using heterologous probes. Pp. 115-158, in Molecular genetic analysis of populations, a practical approach (A.R. Hoelzel, ed). Oxford University Press, New York, NY.

ASPER, E.D. AND D.K. ODELL. 1980. Bottlenose dolphin local herd monitoring, capture, markinng, collection of biological data, and follow-up observations of markerd animals. NMFS Final COntract Report NA-79-GA-C-00027.

AVISE, J. C. 1994. Molecular markers, natural history and evolution. Chapman and Hall, New York, 511 pp.

AVISE, J. C., J. ARNOLD, R. M. BALL, E. BERMINGHAM, T. LAMB, J. E. NEIGEL, C. A. REEB AND N. C. SAUNDERS. 1987. Intraspecific phylogeography: The mitochondrial DNA bridge between population genetics and systematics. Annual Review of Ecology and Systematics, 18:489-522.

BAKER, C. S., S. R. PALUMBI, R. H. LAMBERTSEN, M. T. WEINRICH, J. CALAMBOKIDIS AND S. J. O'BRIEN. 1990. Influence of seasonal migration on the geographic distribution of mitochondrial DNA haplotypes in humpback whales. Nature, 334:238-240.

BAKER, C. S., A. PERRY, J. L. BANNISTER, M. T. WEINRICH, R. B. ABERNETHY, J. CALAMBOKIDIS, J. LIEN, R. H. LAMBERTSEN, J. URBAN RAMIREZ, O. VASQUEZ, P. J. CLAPHAM, A. ALLING, S. J. O'BRIEN AND S. R. PALUMBI. 1993. Abundant mitochondrial DNA variation and world-wide population structure in humpback whales. Proceedings of the National Academy of Sciences, 90:82398243.

BISCHOF, L.L. AND D.A. DUFFIELD. 1994. Relatedness estimation of captive Asian elephants (Elephas maximus) by DNA fingerprinting. Zoo Biology 13:77-82.

BOSKOVIC, R. K.M. KOVACS, M.O. HAMILL AND B.N. WHITE. 1996. Geographic distribution of mitochondrial DNA haplotypes in grey seals (Halichoerus grypus). Canadian Journal of Zoology 74:17871796. 
BRÄGER, S., B. WÜRSIG, A. ACEVEDO AND T. HENNINGSEN. 1994. Association patterns of bottlenose dolphins (Tursiops truncatus) in Galveston Bay, Texas. Journal of Mammalogy, 75:431-437.

BRUFORD, W.A., O. HANOTTE, J.F.Y. BROOKFIELD AND T. BURKE. 1992. Single-locus and multilocus DNA fingerprinting. Pp. 225-270, in Molecular genetic analysis of populations, a practical approach (A.R. Hoelzel, ed). Oxford University Press, New York, NY.

BURT, W.H. 1943. Territoriality and home range concepts as applied to mammals. Journal of Mammalogy 30:25-27.

CONNOR, R.C. AND R.S. SMOLKER. 1985. Habituated dolphins (Tursiops sp.) in Western Australia. Journal of Mammalogy 66(2):398-400.

CRONIN, M.A., S. HILLS, E.W. BORN AND J.C. PATTON. 1994. Mitochondrial DNA variation in Atlantic and Pacific walruses. Canadian Journal of Zoology 72:1035-1043.

DIZON, A. E., S. O. SOUTHERN AND W. F. PERRIN. 1991. Molecular analysis of mtDNA types in exploited populations of spinner dolphins (Stenella longirostris). Pp. 183-202, in The ecology of whales and dolphins (A. R. Hoezel, ed). Special Publication no. 13 of the International Whaling Commission, Cambridge, UK, 311 pp.

DOWLING, T. E. AND W. M. BROWN. 1993. Population structure of the bottlenose dolphin (Tursiops truncatus) as determined by restriction endonuclease analysis of mitochondrial DNA. Marine Mammal Science, 9:138-155.

DUFFIELD, D.A. 1990. Genetic and physiological research applications in marine mammal medicine. Pp. 371-380, in Practical handbook of marine mammal medicine: health, disease and rehabilitation (L.A. Dierauf, ed). CRC Press, Boca Raton, FL.

DUFFIELD, D. A., S. H. RIDGWAY AND L. H. CORNELL. 1983. Hematology distinguishes coastal and off-shore forms of dolphins (Tursiops). Canadian Journal of Zoology, 61:930-933. 
DUFFIELD, D. A., R.S. WELL, D.K. ODELL AND M.A. SOLANGI. 1987. Biochemical genetics of wild bottlenose dolphin populations: implications for population structure and area use. 7th Biennial Conference on Biology of Marine Mammals. Miami, FL (Abstract).

DUFFIELD, D. A. AND R. S. WELLS. 1986. Population structure of bottlenose dolphins: Genetic studies of bottlenose dolphins along the central west coast of Florida. Contract Rept. to National Marine Fisheries Service, Southeast Fisheries Center, Contract No. 45WCNF-5-00366, 10 pp.

DUFFIELD, D.A. AND J. CHAMBERLIN-LEA. 1990. Use of chromosome heteromorphisms and hemoglobins in studies of bottlenose dolphin populations and paternities. Pp. 609-620, in The bottlenose dolphin (S. Leatherwood and R. R. Reeves, eds). Academic Press, San Diego, California.

DUFFIELD, D. A. AND R. S. WELLS. 1991. The combined application of chromosome, protein and molecular data for the investigation of social unit structure and dynamics in Tursiops truncatus. Pp 155169, in The ecology of whales and dolphins (A. R. Hoezel, ed). Special Publication no. 13 of the International Whaling Commission, Cambridge, UK, 311 pp.

DUFFIELD, D.A. AND D. SHELL. 1994. The past, present and future of marine mammal management. Proceedings from the 22nd Annual Conference of the International Marine Animal Trainers Association (S. Shippee and M. Scarpuzzi, eds). Tacoma, WA.

DUFFIELD, D. A., R. S. WELLS, J. S. LENOX AND T. MOORS. 1994. Analysis of paternity in a free-ranging bottlenose dolphin society by DNA fingerprinting and behavioral coefficients of association. International Symposium of Marine Mammal Genetics, La Jolla, California (Abstract).

DUFFIELD, D.A. AND R.S. WELLS. 1997a. The molecular profile of a resident population of bottlenose dolphins, Tursiops truncatus. In prep.

DUFFIELD, D.A., L. BISCHOF AND D.K. ODELL. 1997b. DNA fingerprinting in the West Indian manatee. In prep. 
FUTUYMA, D.J. 1986. Evolutionary biology. Sinauer Associates, Inc. Sunderland, MA. 600 pp.

GILBERT, D.A., C. PACKER, A.E. PUSEY, J.C. STEPHENS AND S.J. O'BRIEN. 1991. Analytical DNA fingerprinting in lions: parentage, genetic diversity, and kinship. Journal of Heredity 82:378-386.

GRUBER, J. A. 1981. Ecology of the Atlantic bottlenosed dolphin (Tursiops truncatus) in the Pass Cavallo area of Matagorda Bay, Texas. M.Sc. thesis, Texas A. \& M. University, College Station, Texas, $182 \mathrm{pp}$.

GUNTER, K.A. 1997. Distribution of R-banded chromosome variants in a bottlenose dolphin (Tursiops truncatus) population. M.S. Thesis. Portland State University, Portland, OR. 98pp.

HARRISON, R. G. 1989. Animal mitochondrial DNA as a genetic marker in population and evolutionary biology. Trends in Ecology and Evolution, 4:6-11.

HEDRICK, P.W. AND P.S. MILLER. 1992. Conservation genetics: techniques and fundamentals. Ecological Applications 2(1):30-46.

HERSH, S. L. AND D. A. DUFFIELD. 1990. Distinction between northwest Atlantic offshore and coastal bottlenose dolphins based on hemoglobin profile and morphometry. Pp. 129-139, in The bottlenose dolphin (S. Leatherwood and R. R. Reeves, eds). Academic Press, San Diego, California, 653 pp.

HERSHKOVITZ, P. 1966. Catalog of living whales. Bulletin of the U.S. National Museum. No. 246.

HOELZEL, A. R. 1991. Analysis of regional mitochondrial DNA variation in the killer whale: Implications for cetacean conservation. Pp. 225-233, in The ecology of whales and dolphins (A. R. Hoezel, ed). Special Publication no. 13 of the International Whaling Commission, Cambridge, UK, $311 \mathrm{pp}$.

HOHN, A.A. 1990. Reading between the lines: analysis of age estimation in dolphins. Pp. 575-585, in The bottlenose dolphin (S. Leatherwood and R. R. Reeves, eds). Academic Press, San Diego, California. 
IRVINE, B. AND R. S. WELLS. 1972. Results of attempts to tag Atlantic bottlenose dolphins (Tursiops truncatus). Cetology, 13:1-5.

IRVINE, A. B., M. D. SCOTT, R. S. WELLS AND J. H. KAUFMANN. 1981. Movements and activities of the Atlantic bottlenose dolphin, Tursiops truncatus near Sarasota, Florida. Fisheries Bulletin U.S., 79:671-688.

JEFFREYS. A.J., V. WILSON, S.L. THEIN. 1985. Hypervariable minisatellite regions in human DNA. Nature 314:67-73.

JEWELL, P.A. 1966. The concept of home range in mammals. Symposium of the Zoological Society of London. 18:85-109.

JONES III, S.C. 1991. Movements of bottlenose dolphins between inlets along the Texas coast. Pg. 37 in Abstracts of the 9th Biennial Conference on the Biology of Marine Mammals. Chicago, Illinois.

KAPPE, A.L., L. VAN DE ZANDE, E.J. VEDDER, R. BIJLSMA AND W. VAN DELDEN. 1995. Genetic variation in Phoca vitulina (the harbour seal) revealed by DNA fingerprinting and RAPDs. Heredity 74:647-653.

LAMONT, M. M., J. T. HARVEY, S. JEFFRIES, R. BROWN, H. H. HUBER, R. DeLONG, AND W. K. THOMAS. 1996. Genetic substructure of the Pacific harbor seal (Phoca vitulina richardsi) off Washington, Oregon and California. Marine Mammal Science, 12:402-413.

LEATHERWOOD, S. AND R.R. REEVES. 1983. The Sierra Club handbook of whales and dolphins. Sierra Club. San Francisco, CA. 302 pp.

LEATHERWOOD, S. AND R.R. REEVES. 1990. Eds. The bottlenose dolphin. Academic Press, San Diego, California. 653 pp.

LEDERBERG, S. AND M. MESELSON. 1964. Degradation of nonreplicating bacteriophage DNA in non-accepting cells. Journal of Molecular Biology 8:263.

LEHMAN, N., P. CLARKSON, L.D. MECH, T.J. MEIER AND R.K. WAYNE. 1992. A study of the genetic relationships within and among wolf packs using DNA fingerprinting and mitochondrial DNA. Behavioral Ecology and Sociobiology 30:83-94. 
LOCKYER, C. 1978. The history and behavior of a solitary wild, but sociable, bottlenose dolphin (Tursiops truncatus) on the west coast of England and Wales. Journal of Natural History 12:513-528.

LYNCH, M. 1991. Analysis of population genetic structure by DNA fingerprinting. Pp: 113-126 in DNA fingerprinting: approaches and applications (T. Burke, A. Dolf, A. Jeffreys and R. Wolff, eds). Birkhauser Verlag, Basel, Switzerland.

MALDONADO, J. E., F. O. DAVILA, B. S. STEWART, E. GEFFEN AND R. K. WAYNE. 1995. Intraspecific genetic differentiation in California sea lions (Zalophus californianus) from Southern California and the Gulf of California. Marine Mammal Science, 11:46-58.

MANIATIS, T., E.F. FRITSCH AND J. SAMBROOK. 1982. Molecular cloning, a laboratory manual. Cold Spring Harbor Laboratory, Cold Spring, NY. 545 pp.

MAZE, K., B. WURSIG AND D. WELLER. 1997. A review of recent and present research on bottlenose dolphins in Texas coastal waters, 1990-1996. www.Texas A\&M University. edu.

McMILLAN, W. O. AND E. BERMINGHAM. 1996. The phylogeographic pattern of mitochondrial DNA variation in the Dall's porpoise Phocoenoides dalli. Molecular Ecology, 5:47-61.

MEAD, J.G. 1975. Preliminary report on the former net fisheries for Tursiops truncatus in the western North Atlantic. Journal of Fishery Research Board of Canada. 32 (7):1155-1162

MEAD, J.G. AND C.W. POTTER. 1990. Natural history of Bottlenose Dolphins along the Central Atlanti c Coast of the United States. Pp. 165-195 in The bottlenose dolphin(S. Leatherwood and R. R. Reeves, eds). Academic Press, San Diego, California, 653 pp.

MESELSON, M. AND R. YUAN. 1968. DAN restriction enzyme from E. coli. Nature, London, 217:1110.

MINKOFF E.C. 1983. Evolutionary Biology. Addison-Wesley Publishing Company, Inc. Reading, MA. 627 pp.

MORITZ, C. 1994. Applications of mitochondrial DNA analysis in conservation: A critical review. Molecular Ecology, 3:401-411. 
NAKAMURA, Y., M. LEPPERT, P. O'CONNELL, R. WOLFF, T. HOLM, M. CULVER, C. MARTIN, E. FUJIMOTO, M. HOFF, E. KUMLIN, R. WHITE. 1987. Variable number of tandem repeat (VNTR) markers for human gene mapping. Science, 235: 1616-1622.

ODELL, D. K. AND ASPER, E. D. 1982. Live Capture, Marking, and resighting of bottlenose dolphins. Final Report, U.S. National Marine Fisheries Service Contract NA80-GA-C-00063. 325 pp.

PALUMBI, S. R., A. P. MARTIN, B. KESSING AND WW. O. McMILLAN. 1991. Detecting population structure using mitochondrial DNA. Pp. 271-278, in The ecology of whales and dolphins (A. R. Hoezel, ed). Special Publication no. 13 of the International Whaling Commission, Cambridge, UK, $311 \mathrm{pp}$.

SAAYMAN, G.S., D. BOWER AND C.K. TAYLER. 1972. Observations on inshore and pelagic dolphins on the sourth-eastern cape coast of South Africa. Koedoe 15:1-24.

SAAYMAN, G.S. AND C.K. TAYLER. 1973. Social organization of inshore dolphins (Tursiops aduncus and Sousa) in the Indian Ocean. Journal of Mammalogy 54:993-996.

SCHAEFF, C., S. KRAUS, M. BROWN, J. PERKINS, R. PAYNE, D. GASKIN, P. BOAG AND B. WHITE. 1991. Preliminary analysis of mitochondrial DNA variation within and between the right whale species Eubalaena glacialis and Eubalaena australis. Pp. 217-223, in The ecology of whales and dolphins (A. R. Hoezel, ed). Special Publication no. 13 of the International Whaling Commission, Cambridge, UK, 311 pp.

SCOTT, G. P. 1990. Management-oriented research on bottlenose dolphins by the Southeast Fisheries Center. Pp. 623-639 in The bottlenose dolphin(S. Leatherwood and R. R. Reeves, eds). Academic Press, San Diego, California. 653pp.

SCOTT, M. D., R. S. WELLS AND A. B. IRVINE. 1990. A long-term study of bottlenose dolphins on the west coast of Florida. Pp. 235244 , in The bottlenose dolphin (S. Leatherwood and R. R. Reeves, eds). Academic Press, San Diego, California, 653 pp.

SHANE, S. H. 1980. Occurrence, movements and distribution of bottlenose dolphin, Tursiops truncatus, in southern Texas. Fisheries Bulletin, 78: 593-601. 
SHANE, S. H. 1990. Behavior and ecology of the bottienose dolphin at Sanibel Island, Florida. Pp. 245-265, in The bottlenose dolphin (S. Leatherwood and R. R. Reeves, eds). Academic Press, San Diego, California, 653 pp.

SHANE, S. H., R. S. WELLS AND B. WÜRSIG. 1986. Ecology, behavior, and social organization of the bottlenose dolphin: A review. Marine Mammal Science, 2:34-63.

SHANE, S.H. 1977. The population biology of the Atlantic bottlenose dolphin, Tursiops truncatus, in the Aransas Pass area of Texas. M.Sc. thesis, Texas A\&M University, College Station, TX 77843

SOLANGI, M. A. AND G. E. DUKES. 1983. Atlantic bottlenose dolphin, Tursiops truncatus, herd studies in the Mississippi Sound, U.S.A.: Capture, freeze marking and biological sampling. NOAA, National Marine Fisheries Service, Contract No. NA82-GA-C-00023, 178 pp.

SOUTHERN, E. 1975. Detection of specific sequences among DNA fragments separated by gel electrophoresis. Journal of Molecular Biology, 98:503.

STANLEY, H. F., S. CASEY, J. M. CARNAHAN, S. GOODMAN, J. HARWOOD AND R. K. WAYNE. 1996. Worldwide patterns of mitochondrial DNA differentiation in the harbor seal (Phoca vitulina). Molecular Biology and Evolution, 13:368-382.

STEPHENS, J.C., D.A. GILBERT, N. YUHKI, AND S.J. O'BRIEN. 1992. Estimation of heterozygosity for single-probe multilocus DNA Fingerprints. Molecular Biology Evolution, 9(4):729-743.

STEVENS, T. A., D. A. DUFFIELD, E. D. ASPER, K. G. HEWLETT, A. BOLZ, L. J. GAGE AND G. D. BOSSART. 1989. Preliminary findings of restriction fragment differences in mitochondrial DNA among killer whales (Orcinus orca). Canadian Journal of Zoology, 67:2592-2595.

URIAN, K. W., D. A. DUFFIELD, A. J. READ, R. S. WELLS AND D. D. SHELL. 1996. Seasonality of reproduction in bottlenose dolphins, Tursiops truncatus. Journal of Mammalogy, 77:394-403. 
WADA, S. 1991. Genetic variability and differentiation of mitochondrial DNA in minke whales. Pp. 203-215, in The ecology of whales and dolphins (A. R. Hoezel, ed). Special Publication no. 13 of the International Whaling Commission, Cambridge, UK, 311 pp.

WALKER, W. A. 1981. Geographic variation in morphology and biology of bottlenose dolphins (Tursiops) in the eastern North Pacific. U.S. Department of Commerce, National Marine Fisheries Service, Administrative Report LJ-81-03C, 54 pp.

WATSON, J.D., M. GILMAN, J. WITKOWSKI, AND M. ZOLLER. 1992. Recombinant DNA Second Edition. W.H. Freeman and Company, New York, NY, pp 626.

WELLS, R. S. 1991. The role of long-term study in understanding the social structure of a bottlenose dolphin community. Pp. 199-225, in Dolphin societies: Discoveries and puzzles (K. Pryor and K. S. Norris, eds). University of California Press, Berkeley, California, $397 \mathrm{pp}$.

WELLS, R. S., A. B. IRVINE AND M. D. SCOTT. 1980. The social ecology of inshore odontocetes. Pp. 263-317, in Cetacean behavior:

Mechanisms and functions (L. M. Herman, ed.). J. Wiley \& Sons. New York, 463 pp.

WELLS, R. S., M. D. SCOTT AND A. B. IRVINE. 1987. The social structure of free-ranging bottlenose dolphins. Pp. 247-305, in Current mammalogy, Vol. 1 (H. Genoways, ed.). Plenum Press, New York, 519 pp.

WELLS, R.S., M.D. SCOTT, A.B. IRVINE, AND P.T. PAGE. 1981. Observations during 1980 of bottlenose dolphines, Tursiops truncatus marked during 1970-1976, on the west coast of Florida. NMFS Final Report NA80-GA-A-195.

WELLS, T.P. DOHL, L. J. HANSEN, A. B. BALDRIDGE AND D.L. KELLY. 1983. Extrodinary movements of bd (Tursiops sp.) Abstract, American Society of Mammalogist Annual Meeting. Humboldt State University, Arcata, CA.

WICKINGS J.E. 1993. Hypervariable single and multi-locus DNA polymorphisms for genetic typing of non-human primates. Primates 34(3):323-331. 
WÜRSIG, B. AND S. K. LYNN. 1996. Movements, site fidelity, and respiration patterns of bottlenose dolphins on the central Texas coast. NOAA Technical Memorandum NMFS-SEFSC-383, 43 pp. + 10 Tables, 13 Figures, and 6 Appendices.

WÜRSIG, B. AND G. HARRIS. 1990. Site and association fidelity in Bottlenose Dolphins off Argentina. Pp. 361-365, in The bottlenose dolphin (S. Leatherwood and R. R. Reeves, eds). Academic Press, San Diego, California, 653 pp.

WÜRSIG, B. AND M. WÜRSIG. 1977. The photographic determination of group size, composition, and stability of coastal porpoises (Tursiops truncatus). Science 198:755-756.

WÜRSIG, B. AND M. WÜRSIG. 1979. Behavior and ecololgy of bottlenose porpoises, Tursiops truncatus, in the South Atlantic. Fishery Bulletin (U.S.) 77:399-442.

VAN WAEREBEEK, K., J.C. REYES, A.J. READ, AND J.S. MCKINNON. 1990. Preliminary observations of bottlnose dolphins from the Pacific Coast of South America, Pp. 143-154, in The bottlenose dolphin (S. Leatherwood and R. R. Reeves, eds). Academic Press, San Diego, California, 653 pp. 
TOTAL DNA EXTRACTION FROM BLOOD

1. Remove proteinase $\mathrm{K}$ from freezer and allow to that while proceeding with the following steps.

2. Pipette plasma into $15 \mathrm{ml}$ polypropylene tube.

3. Spin plasma at $1700 \times \mathrm{g}$ (3000 rpm in Samon DPR-6000) for $20 \mathrm{mins}$. to pellet platelets.

4. If red blood cells are present, suspend cells in 5.5 times the pellet volume of cold haemolysis solution. Use low speed vortex to suspend cells.

5. Place at -20 degrees $C$ for 3 mins. until color turns from red to wine.

6. Spin at $1700 \times \mathrm{g}$ (300 rpm) for 20 mins.

7. Pour off supernatant.

8. Repeat until RBC contamination is negligible. May not be necessary to do this step in the first place.

9. Save pellet for later.

White Blood Cell Layer

1. Pipette WBC layer into polystyrene tube.

2. Add 5.5 times the pellet volume of cold haemolysis solution and vortex at low speed.

3. Place at -20 degrees $C$ for a few mins. until color turns from red to wine.

4. Spin at 4.5 in tabletop centrifuge for 20 mins.

5. Pour off supernatant and repeat if necessary OR pipette off supernatant and goto next steps. 
6. Pipette WBC pellet into the polypropylene tube containing the platelet pellet $\mathrm{OR}$ add about $0.5 \mathrm{ml}$ STE to the WBC tube, vortex on low, and then pipette $W B C^{\prime}$ s into platelet tube.

7. Add $1 \mathrm{ml}$ STE to $W B C$ tube to rinse remaining $W B C^{\prime} s$ from sides of tube and pipette into platelet tube. Repeat.

8. Add STE to platelet/WBC solution to bring the volume up to $6.0 \mathrm{mls}$.

9. Add $500 \mathrm{ul}$ proteinase $\mathrm{K}(1 \mathrm{mg} / \mathrm{ml}$ in water) while mixing gently.

10. Add 500 ul $10 \%$ SDS (or 200 ul 25\% SDS) dropwise while mixing.

Solution should clarify and become viscous as membranes break and cell contents are released.

11. Place in 37 degrees $C$ incubator at a slight angle (to increase surface area) overnight (16-20 hrs.)

*DO NEXT SECTION UNDER FUME HOOD WEARING PROTECTIVE GLOVES*

1. Add 1 volume PCIA.

2. Mix gently 15 mins using a tube rotator.

3. Spin at $1600 \mathrm{xg}$ ( $2750 \mathrm{rpm}$ for $20 \mathrm{mins}$.) in a swinging bucket centrifuge (Damon DPR-6000)

4. Remove upper DNA layer with a long-tipped Pasteur pipette (may want to break it off near the should to decrease the vortex/suction of the pipette, which can bring the white protein layer up with the DNA.

5. Place the DNA into a fresh polypropylene tube and save the old tube in case need to re-extract later.

6. Repeat PCIA extraction two more times.

7. Repeat above extraction twice using CIA to remove traces of phenol.

8. Transfer last DNA layer to a $30 \mathrm{ml}$ corex tube (or $50 \mathrm{ml}$ Falcon).

9. Add 667 ul NaOAc. 
10. Add 3 volumes -20 degrees $C$ absolute ethanol; seal the top of the tube with parafilm (or put cap on $50 \mathrm{ml} \mathrm{Falcon}$ ) and mix by inverting. Should see a white fluffy cloud appear which is the DNA. May not see it if the ethanol is not cold enough.

11. Place at -20 degrees $C$ for at least $1 \mathrm{hr}$. to precipitate the DNA. DNA can be stored at -20 degrees for years at this point.

12. Spin at $12,000 \times g(10,000 \mathrm{rpm}$ for Sorvall RC2-B; SS-34 rotor $)$ at 4 degrees $C$ for 40-50 mins.

13. Pour off supernatant.

14. Add approximately $2 \mathrm{mls} 75 \% \mathrm{EtOH}$, swirl slowly around tube to remove excess salts.

15. Spin at $12,000 \times \mathrm{g}(10,000 \mathrm{rpm})$ for $30 \mathrm{mins}$.

16. Remove supernatant with a Pasteur pipette.

17. Vacuum dry pellet, or let dry at least $24 \mathrm{hrs}$. with a cap of parafilm into which many needle holes have been poked to let in air, and place a kimwipe or two over the top to keep particle or debris from entering the tube through the holes.

18. Re-suspend pellet in TE ( $\mathrm{pH}$ 8.0). Start with $50 \mathrm{ul}$ and gradually increase volume. May add up to $2 \mathrm{mls}$ or more. Want a viscous but pipettable concentration. If DNA is still mostly in one large clump need to continue adding TE until mixture is homogenous and able to be pipetted with out getting stuck in the pipette tip.

19. Once dissolved, remove to an eppendorf tube(s) and store at 4 degrees $C$.

\section{DNA RESTRICTION PROCEDURE}

1. Prepare a 37 degrees $C$ water bath and a 65 degree $C$ water or oil bath.

2. Place in eppendorf tubes in the following order: 
${ }_{* * * * \text { Remember to VORTEX and SPIN the BUFFER and DNA }}^{* * * *}$

a) water ( $2 X D$, no need for it to be sterile)

b) buffer (1/10 volume) IMPORTANT

c) DNA

d) enzyme (2-3 units/ug DNA) Make sure it is also $1 / 10$ total volume

3. Vortex, spin, vortex, spin.

4. Incubate samples at 37 degrees $C$ for $4-5$ hours to allow restriction.

Consult manufactures instructions on incubation times for each specific enzyme.

5. Add $1 / 10$ total volume $10 \mathrm{X}$ stop dye to terminate the reaction.

6. Spin, vortex, spin, vortex, spin. Can store sample in the refrigerator for a few days at this point.

7. If samples were stored, vortex and spin twice. If not then place directly into 65 degrees $C$ water or oil bath for 3 mins. to avoid sticky ends.

8. Place on ice and load into wells. 
1. Determine the desired percentage concentration. $1 \%$ works well for mitochondrial DNA work, $0.8 \%$ works well for fingerprinting.

2. Combine the agarose and $1 \mathrm{XTBE}$ in a microwaveable bottle.

EXAMPLE: For a $1 \%$ gel, use $3.0 \mathrm{~g}$ agarose and $300 \mathrm{ml} 1 \mathrm{XTBE}$. For a $0.8 \%$ gel use $2.4 \mathrm{~g}$ agarose and $300 \mathrm{ml} 1 \mathrm{XTBE}$.

3. Swish around by hand to mix the powder into the liquid.

4. Place uncapped bottle in the microwave and set on high until liquid begins to boil (about 5-8 mins). Once boiling, count to 20 and remove from oven(wearing oven mitts). Swish around by hand until last remaining crystals go into solution. Replace cap loosely on top and cool on a shaker set at a low enough speed as to not create bubbles.

5. Prepare gel rig for use by pulling up the gates to the buffer reservoirs and placing the appropriate size comb near the top (left hand side of rig, or negative electrode end). Make sure to leave a microscope slide thickness of space between the bottom of the rig and the tips of the comb teeth. You don't want the comb cutting all the way through the gel.

6. When the agarose/TBE bottle is cool enough to hold comfortably, remove it from the shaker and pour the agarose into the gel rig starting in one corner and letting the solution spread out from there. 
7. Try to pour slowly to avoid bubbles from occurring, but if they do, poke them out with the tip of a rolled up kimwipe.

8. Let gel harden. It is ready when it appears opaque from the side and resists when you gently press a finger carefully in one corner.

9. Pour enough $1 \mathrm{XTBE}$ onto gel $t$ cover the surface and to move around the comb.

10. Gently remove the comb by lifting straight up on it. Rinse comb immediately with water.

11. Gently push down the gates to the buffer reservoirs.

12. Pour more 1 XTBE over gel to fill both reservoirs and leave about $1 / 2$ inch solution over gel surface. This usually takes about $1000 \mathrm{mls}$.

13. Gel is now ready to load and run.

\section{NICK-TRANSLATION}

1. Thaw out dNTP's (the tube that contains dGTP, dCTP, and dTTP), biotinylated dATP, sterile water and stop buffer.

2. Vortex to mix solutions.

3. In the order listed, mix in an eppendorf tube the following:

a. 87.5 ul sterile water

b. 25 ul dNTP's

c. 12.5 ul biotinylated dATP

d. 100 ul mixed plasmid DNA

225 ul total volume

4. Prepare a 15 degree $C$ waterbath (a beaker with water and ice available to add as needed).

5. Vortex to mix and spin down briefly in microfuge to bring down the solution. Repeat.

6. Add 25 ul of DNA polymerase I, keeping it on ice or over the freezer. 
7. Vortex to mix and spin down briefly in microfuge to bring down solution.

8. Incubate in 15 degrees $C$ waterbath for 90 mins. Check temperature about every 20 mins.

9. Add 25 ul stop buffer (vortex before using).

10. Add 6.25 ul $5.0 \%$ SDS (can make this from stock solution of $25 \%$ SDS by putting $200 \mathrm{ul} 25 \%$ SDS into an eppendorf and adding $800 \mathrm{ul}$ $2 X D$ sterile water and vortexing).

11. Add 85 ul 3.0M NaOAc

12. Add 703 ul cold absolute ethanol

13. Vortex to mix and spin down briefly in microfuge to bring down solution. Spin in cold room if possible.

14. Place at -20 degrees $C$ for at least $30 \mathrm{~min}$. to precipitate DNA (can leave overnight at this point).

15. Spin at $10,000 \mathrm{rpm}$ in microfuge at 4 degrees $C$ for 30 mins. to pellet DNA. Spin in cold room if possible. Unincorporated nucleotides will remain in solution.

16. Pipette off supernatant

17. Re-suspend pellet in $280 \mathrm{ul} \mathrm{TE}$ ( $\mathrm{pH} 8.0$ )

18. Repeat steps 11-16, then go to step 19.

19. Vacuum dry pellet until all traces of ethanol are gone (takes about 30 mins.).

20. Re-suspend pellet in $500 \mathrm{ul} \mathrm{TE}$ ( $\mathrm{pH} 8.0$ )

21. Store at 4 degrees $C$. Can be stored up to 2 months prior to use. 
SOUTHERN TRANSFER

Day 1

Prepare Gel for Transfer

1. Restrict samples to be run on agarose gel (see DNA restriction procedure).

2. Run restricted samples on gel. Use anywhere from 5.0 to $20.0 \mathrm{ul}$ of sample per lane, depending on the type of enzyme and species of animal used. You will have to run some test lanes at various concentrations to determine what will work best in a given situation. Try to use a low voltage over a long period to prevent lanes from smearing or "smiling"; start by running at $150 \mathrm{v}$ for 10 min. to pull samples out of wells, then decrease voltage and run at $40 \mathrm{v}$ for 8-12 hrs. for a mtDNA blot, and $25 \mathrm{hrs}$. for a fingerprinting blot.

3. Make sure power is off and electrodes are removed Wearing gloves, carefully remove gel from gel rig and place in a glass dish such as a lasagna pan. Be careful to support the gel with both hands, and try not to chip the edges off or break it in any way. Should a break occur, continue through the following steps anyway, carefully piecing it back together.

4. Stain gel with $40 \mathrm{ul}$ Ethidium Bromide (EtBr) $(10 \mathrm{mg} / \mathrm{ml})$ in $500 \mathrm{ml}$ 1XD $\mathrm{H}_{2} \mathrm{O}$ with gentle agitation for approximately $5 \mathrm{~min}$. Be EXTREMELY CAREFUL not to spill the EtBr and WEAR GLOVES during this entire process.

5. Pour off stain into a container and dispose of as hazardous waste.

6. Destain gel in $500 \mathrm{ml} 1 \mathrm{XD} \mathrm{\textrm {H } _ { 2 }} 0$ for approximately $30 \mathrm{mins}$. to $1 \mathrm{hr}$. (longer destaining makes for paler results).

7. Pour destain into waste container, and carefully clean everything touched. Can use UV light to check area for traces of EtBr. 
Discard your gloves into waste container if you cannot do the following steps without touching door handles, photographic equipment, etc. REMEMBER, ALWAYS WEAR GLOVES WHEN TOUCHING THE GEL ITSELF!

8. Remove gel from lasagna pan and photograph under long wave UV light with a ruler placed alongside the gel, with 0 directly in line with the sample wells. For faint bands, expose the gel to the film for 2 seconds, for bright bands, 1 second exposure should be adequate. Be sure to wear protective glasses while working with the UV light.

9. Return gel to lasagna pan and clean all surfaces the gel touched.

Discard all EtBr contaminated waste into appropriate waste container.

10. Add $0.25 \mathrm{M} \mathrm{HCL}$ solution to cover gel and agitate slowly for about 30 min. OR until bromophenol blue dye turns yellow. This breaks DNA into smaller pieces to facilitate better transfer.

11. Pour off solution (can pour directly into sink).

12. Add denaturing solution to cover gel and agitate slowly for $30 \mathrm{~min}$. OR until the now yellow bands turn blue again. This turns DNA single-stranded to facilitate better transfer.

13. Pour off solution (into sink).

14. Add neutralizing solution to cover gel, agitate slowly for $30 \mathrm{~min}$.

15. Pour off solution (into sink).

16. Blot the top of the gel dry with kimwipes (don't use paper towel or anything that will leave fibers or lint on gel). Top of gel being the side with the well openings.

Set up for Transfer

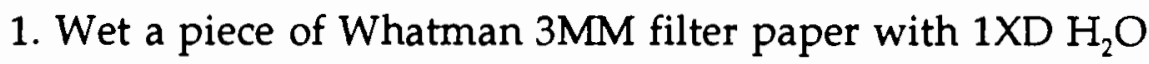


-paper should be the same width as gel but long enough to form a wick between the buffer reservoirs

2. Place paper in gel rig making sure no air bubbles are trapped underneath. Make sure top of gel is dry.

3. Place gel upside-down (dry side down) on top of paper, making sure no air bubbles are trapped underneath. Carefully press gel with fingertips to work air bubbles out to the sides of the gel where they will escape.

4. Cut a piece of Hybond-N nylon membrane to fit the gel from the wells down. Make a small cut on the upper right of the membrane to identify the placement of the membrane.

5. Carefully place the membrane on gel where transfer is to occur, lining up the top edge of the membrane with the wells and making sure no air bubbles are trapped underneath.

6. Individually place 2 pieces of wet (with $1 \mathrm{XD}_{2} \mathrm{O}$ ) Whatman $3 \mathrm{MM}$ filter paper on top of membrane, making sure no air bubbles are rapped underneath. The paper should be the exact size of the entire gel.

7. Stack single-fold paper towels on top of Whatman paper. Start with 6 individually placed towels, pressing each one down to get them wet to facilitate better wicking. Then add enough towels to reach 10-12 cm. in height.

8. Compress using the lasagna pan filled with tap water.

9. Add 20X SSC to buffer reservoirs so that ends of filter paper are immersed in buffer (100-150 ml/reservoir).

10. Allow transfer to proceed for approximately 12-14 hours. Transfer can go longer with no adverse affects. 
Day 2

Hybridization with Probe

1. Turn on water bath-shaker to heat 65 degrees $C$ the night before.

2. Carefully remove membrane.

3. Place gel back into lasagna pan and repeat $\mathrm{EtBr}$ staining and destaining steps from the first day. You should come up with a gel that is devoid of any orange bands when visualized under UV light. This indicates that the transfer did occur. If it appears that the transfer did not occur, run gelthrough preparation for transfer and transfer steps again. After transfer the gel will be very flat. If transfer did work, dispose of the gel in a discard container or bucket with any other EtBr waste generated.

4. Place the membrane in a shallow flat-bottom container and rinse with a small amount of $2 X$ SSC to remove any adhering agarose. Best to do this twice.

5. Place membrane on Saran Wrap (most other wraps are UV impervious), and allow to air dry (takes 2 or more hours this way) or dry in an incubator set at no more than 37 degrees $C$ (takes about $1 / 2-1 \mathrm{hr}$. this way). Use forceps to turn membrane over periodically to ensure complete dryness.

6. Once dry, wrap in saran wrap so that the DNA side has a single smooth layer of wrap over it and place DNA side down (cut in membrane will be in upper right corner) on a UV transilluminator for 8 minutes to cross-link the DNA to the membrane. This is important because if the DNA is not linked to the membrane it will wash off when you start the rinsing process. Once cross-linked the membrane can be stored in a dark place for years with no ill effects. 
7. Place membrane in hybridization bag and heat seal bag on one each end.

8. Cut off corner of bag and push out air bubbles.

9. Add $25 \mathrm{ml}$. of pre-hybridization solution that had been heated to 37 degrees C. Make the pre-hyb. solution just prior to using because it breaks down over time.

10. Add $250 \mathrm{ul}$ of denatured salmon sperm DNA to bag to a final concentration of $100 \mathrm{ug} / \mathrm{ml}$.

11. Seal cut in corner by pinching with fingers and tip bag back and forth to mix solutions and soak membrane.

12. Carefully remove air bubbles from the bag by running a ruler along outside of bag, gently coaxing bubbles out the cut in the corner. Try not to squeeze any of the solution out.

13. Heat seal corner with double seal.

14. Place in 65 degrees $C$ water bath-shaker for at least 2 hrs. Keep bag flat and submerged.

15. Nick-translate probe at this point or use what has been prepared the previous day.

16. Place a beaker of water on a hot plate and heat to boiling.

17. Place nick-translated probe in a raft and float it in the boiling water. Let the probe heat for $10 \mathrm{~min}$. then place on ice.

18. Heat $25 \mathrm{ml}$ pre-hybridization solution to 37 degrees $C$ (it will become clear when ready to use).

19. Cut corner of bag ( the opposite one from the previous cut) and pour out pre-hyb. solution. Need another $100 \mathrm{ug} / \mathrm{ml}$ of salmon sperm DNA.

20. Add hybridization solution.

21. Add heat-treated probe to bag. Rinse eppendorf with $100 \mathrm{ul} \mathrm{TE}$, vortex, spin, and add it to bag as well $(100 \mathrm{ng} / \mathrm{ml})$. 
22. Temporarily seal cut with pinched fingers and tip back and forth to mix solutions.

23. Remove air bubbles by running ruler along outside of bag as before, trying not to lose any solution.

24. Double heat seal end of bag.

25. Place in 65 degrees $C$ water bath shaker for at least 12 hours (overnight).

Day 3

Stringency Washes

1. Remove membrane from bag by cutting bag along longest edge and removing membrane with forceps. DO NOT DISCARD SOLUTION. Hybridization solution can be kept for later reuse by sealing it in the bag, labeling and dating the bag and storing it at 20 degrees $C$. Two used bags is equal to one new bag. Do not need to add new probe to old bags; just boil the bags and bring solutions up to temp. REUSE SOLUTIONS ONLY ONCE.

2. Incubate membrane with $50 \mathrm{ml} 2 \times$ SSC at 65 degrees $C$ for $15 \mathrm{~min}$.

This can be done in a tight fitting sealed container or a new hybridization bag. Remove air bubbles as before.

3. Replace with $50 \mathrm{ml} 2 \times$ SSC $/ 0.1 \%$ SDS and incubate at 65 degrees $C$ for $30 \mathrm{~min}$. Remove air bubbles as before.

4. Replace with $50 \mathrm{ml} 1 \mathrm{XSSC} / 0.1 \%$ SDS and incubate at 65 degrees $\mathrm{C}$ for $10 \mathrm{~min}$.

5. Remove membrane from bag and place membrane in a plastic container so that it lies flat on the bottom.

6. Briefly rinse membrane with $2 X$ SSC to remove some of the $1 X$ SSC and SDS. 
Filter Blocking

1. Pour off the $2 X$ SSC.

2. Cover membrane with Buffer 1 and agitate by hand at room temperature for $1 \mathrm{~min}$.

3. Pour off Buffer 1.

4. Incubate membrane in $30 \mathrm{ml}$ Buffer 2 at 65 degrees $C$ for $1 \mathrm{hr}$. in a water bath-shaker. The membrane should be sealed in a hybridization bag.

Application of Detection System

1. Remove membrane from the bag and place in plastic container.

2. Make SA-AP solution just prior to use. Be sure to wear gloves. -in a POLYPROPYLENE tube, mix 1 ul SA-AP for each $1.0 \mathrm{ml}$ of Buffer 1.

- for one membrane, use 10 ul SA-AP in $10.0 \mathrm{ml}$ Buffer 1.

3. Pour SA-AP solution over membrane.

4. Gently agitate by hand for $10 \mathrm{~min}$. at room temperature. Periodically turn membrane over using forceps to ensure complete coverage of membrane with solution.

5. Decant solution.

6. Wash membrane with 20 -fold excess of Buffer 1 than used during SAAP conjugation (in this case use $200 \mathrm{ml}$ ).

7. Gently agitate for $15 \mathrm{~min}$. at room temperature (use a shaker if available).

8. Repeat wash steps 6 and 7.

9. Wash membrane in approximately $100 \mathrm{ml}$ Buffer 3 for $10 \mathrm{~min}$. at room temperature with gently agitation.

Visualization

The visualization solution is very dangerous. Check with your chemical handling/disposal facilities as to proper handling and 
disposal techniques in your area. WEAR GLOVES when handling solution, and a mask and/or fume hood is recommended.

1. Prepare dye solution just prior to use.

-in POLYPROPYLENE tube mix:

$-7.5 \mathrm{ml}$ Buffer 3

-33 ul NBT solution

-mix gently by inverting capped tube.

-add 25 ul BCIP solution, invert as above.

2. Decant solution from step 9. above.

3. Place membrane in hybridization bag and heat seal twice.

4. Cut corner of bag.

5. Add dye solution by carefully pipetting into bag. Place the soiled pipette on a thick mat of paper towel to await proper cleaning.

6. DO NOT REMOVE AIR BUBBLES WITH RULER as the solution is dangerous and may squirt out through the cut in the bag. Double heat seal the bag, and be sure to clean up any solution that may be on the outside of the bag or that may have contaminated the sealer.

7. Place the bag flat on some paper towels and try to arrange any bubbles to the edges of the bag so that the membrane itself is covered with he solution. Place the bag in a dark place (i.e. on a cupboard shelf) to allow color development to proceed. Invert bag occasionally to move solution over membrane. Visualization of mtDNA bands should occur between $1 / 2$ to 3 hours. Check progress every 15 min. or so to make sure the background doesn't become too dark.

8. Using forceps carefully remove membrane from bag and place in plastic container. DO NOT POUR OUT SOLUTION but heat seal bag twice and dispose in proper receptacle. 
9. Add termination solution to cover filter. Swish around by hand for 23 mins, then decant solution.

10. Add termination solution to cover filter and gently agitate for 10 mins at room temperature.

11. Dry membrane at room temperature or in 37 degree $C$ incubator.

12. Photograph (best) or photocopy (poor) membrane, placing a ruler along one side with the 0 at the origin (top of membrane where wells were situated).

Photocopying can be enhanced by using a yellow or blue transparency between the membrane and the machine.

13. Store membrane wrapped in saran wrap in a dark place.

14. If desired, you can wash off the probe and re-probe this membrane (see Biotin Probe Wash protocol).

\section{MATERIALS REQUIRED FOR DNA EXTRACTION FROM WHOLE BLOOD}

$15 \mathrm{ml}$ conical polypropylene screwcap tubes

$15 \mathrm{ml}$ conical polystyrene screwcap tubes

Safeguard tabletop centrifuge

Damon DPR-6000 centrifuge

Tube rotator

Fume Hood

long-tipped Pasteur pipettes

$1.0 \mathrm{ml}$ pipettes

-20 degree $C$ freezer

37 degree $C$ incubator

1000 ul micropipette with tips

vacuum drier

parafilm and kimwipes 
STOCK SOLUTIONS FOR DNA EXTRACTION

Haemolysis solution

10:1 $0.144 \mathrm{M} \mathrm{NH}_{4} \mathrm{Cl}: 0.01 \mathrm{M} \mathrm{NH}_{4} \mathrm{HCO}_{3}$

- $3.85 \mathrm{~g}$ solid $\mathrm{NH}_{4} \mathrm{Cl}$ in $500 \mathrm{ml}$ sterile $2 \mathrm{XD} \mathrm{H}_{2} \mathrm{O}$

- $0.4 \mathrm{~g}$ solid $\mathrm{NH}_{4} \mathrm{HCO}_{3}$ in $50 \mathrm{ml}$ sterile $2 \mathrm{XD} \mathrm{H}_{2} \mathrm{O}$

-mix the two solutions together

Proteinase $\mathrm{K}$

$1.0 \mathrm{mg} / \mathrm{ml}$ in sterile $2 X^{2} \mathrm{H}_{2} 0$

-for $50 \mathrm{ml}$

- weigh out $50 \mathrm{mg}$ proteinase $\mathrm{K}$

- dissolve in $50 \mathrm{ml}$ sterile $2 \mathrm{XD} \mathrm{H}_{2} \mathrm{O}$

-store at -20 degrees $C$

CIA

24:1

-for $250 \mathrm{mls}$

- $240 \mathrm{mls}$. chloroform

- $10 \mathrm{mls}$ isolamyalchohol

- combine under fume hood into sterile bottle 
PCIA

$1: 1$

- for $200 \mathrm{mls}$

$-100 \mathrm{mls}$ CIA

- $100 \mathrm{mls}$ equilibrated phenol ( $\mathrm{pH} 7.6)$

Phenol Equilibration: CAUTION. Use fume hood and gloves!

1. Set up ring stand and separation funnel in fume hood.

2. Measure out 8-hydroxyquiniline $(0.1 \mathrm{~g} / 100 \mathrm{ml}$ phenol) wearing mask and gloves. DO NOT SPILL OR INHALE.

3. Pipette desired amount of phenol into separation funnel making sure the bottom stopper is closed.

4. Add the appropriate amount of 8-hydroxyquiniline.

5. Cap funnel, remove from stand and mix by gently tipping back and forth.

6. Pipette into separation funnel an equal volume of $1 \mathrm{M}$ Tris.

7. Mix as in step 5. Let settle.

8. Remove cap, place clean bottle under bottom of funnel and decant the bottom phenol layer into it.

9. Decant the Tris into a discard bottle and test for $\mathrm{pH}$ with litmus paper or $\mathrm{pH}$ meter. Should be close to $7.6 \mathrm{pH}$.

10. Close bottom of funnel and pour the phenol back in.

11. Repeat steps 6 through 9 using $0.1 \mathrm{M}$ Tris this time; and decant phenol into a very clean bottle this time.

12. Clean equipment immediately with water in a well ventilated area and check with your chemical disposal facilities on where to store/dispose of the Tris which now contains small amount of phenol. 
EQUIPMENT REQUIRED FOR SOUTHERN TRANSFER

1 gel rig

1 Pyrex dish (lasagna pan) to fit gel

shaker

UV transilluminator

Whatman $3 \mathrm{MM}$ filter paper

1 nylon transfer membrane

Saran wrap

Single fold paper towels

5 hybridization bags

Heat sealer for hybridization bags

65 degrees $C$ water bath/shaker

Plastic container for room temperature agitations

2 - $15 \mathrm{ml}$ screw top polypropylene tubes

Film and camera setup

Ruler

UV protective glasses

gloves

SOLUTIONS REQUIRED FOR SOUTHERN TRANSFER

Restriction enzymes

Agarose TBE

Ethidium Bromide (EtBr $10 \mathrm{mg} / \mathrm{ml}$ )

0.25M HCL

1XD H $\mathrm{H}_{2} \mathrm{O}$ 
2XD $\mathrm{H}_{2} \mathrm{O}$

Denaturing solution

Neutralizing solution

20X SSC

$2 \times$ SSC

Pre-hybridization solution

Hybridization solution

Salmon sperm DNA

Nick-translation probe

$2 \times \mathrm{SSC} / 0.1 \%$ SDS

$1 \times$ SSC / $0.1 \%$ SDS

Buffer 1

Buffer 2

SA-AP solution

Buffer 3

Dye solution

Termination solution

STOCK SOLUTIONS

$0.25 \mathrm{M} \mathrm{HCL}$

-for 1 litre

$21.0 \mathrm{ml}$ concentrated HCL $(12 \mathrm{~N}=12$ Molar $)$

$2 \mathrm{XD} \mathrm{H}_{2} \mathrm{O}$ (sterile) to 1 litre

$1 \mathrm{M}$ Tris-HCL

121.1 Tris base

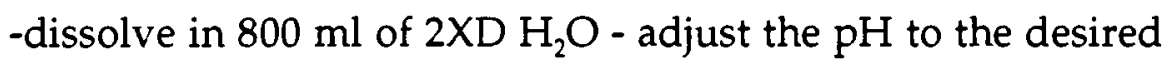
value by adding concentrated $\mathrm{HCL}$ 
-allow solution to cool to room temperature before making final adjustments to $\mathrm{pH}$

-make up volume to 1 litre

-dispense into aliquots

-autoclave

desired $\mathrm{pH} \quad$ approximate amount of $\mathrm{HCL}$

7.4

$70 \mathrm{ml}$

7.5

$60 \mathrm{ml}$

8.0

$42 \mathrm{ml}$

***if solution has a yellow color, discard and obtain better quality Tris ${ }^{* * *}$

0.5 EDTA

$46.52 \mathrm{~g}$ disodium ethylene diamine tetraacetate $\mathrm{H}_{2} \mathrm{O}$

- dissolve in $150 \mathrm{ml} 2 \mathrm{XD} \mathrm{H}_{2} \mathrm{O}$ (won't dissolve until $\mathrm{pH}$ is 7.0)

- stir on magnetic stirrer

- adjust $\mathrm{pH}$ to 8.0 by addition of $\mathrm{NaOH}$ pellets (approximately 5)

- adjust volume to $250 \mathrm{ml}$

- dispense into aliquots

- autoclave

TE

$10 \mathrm{mM}$ Tris-HCL (pH 8.0)

$1 \mathrm{mM}$ EDTA (pH 8.0)

- for $100 \mathrm{ml}$

- autoclave bottle before using

$1.0 \mathrm{ml} 1 \mathrm{M}$ Tris-HCL ( $\mathrm{pH} \mathrm{8.0)}$

$0.2 \mathrm{ml} 0.5 \mathrm{M}$ EDTA 
$2 \times D \mathrm{H}_{2} \mathrm{O}$ to $100 \mathrm{ml}$ (sterile)

5X TE

Autoclave bottle before using

$-5.0 \mathrm{ml} 1 \mathrm{M}$ Tris-HCL (pH 8.0)

$-1.0 \mathrm{ml} 0.5 \mathrm{M}$ EDTA

- 2XD $\mathrm{H}_{2} \mathrm{O}$ to $100 \mathrm{ml}$ (sterile)

$5 \mathrm{M} \mathrm{NaCl}$

$146.1 \mathrm{~g} \mathrm{NaCl}$

- dissolve in $400 \mathrm{ml} 2 \times \mathrm{XD} \mathrm{H}_{2} \mathrm{O}$

-adjust volume to $500 \mathrm{ml}$

- dispense into aliquots

- autoclave

Denaturing solution

$1.5 \mathrm{M} \mathrm{NaCl}$

$0.5 \mathrm{M} \mathrm{NaOH}$

- for 1 litre

$87.66 \mathrm{~g} \mathrm{NaCl}$

$20.0 \mathrm{~g} \mathrm{NaOH}$

2XD $\mathrm{H}_{2} \mathrm{O}$ to 1 litre

Neutralizing solution

$1.5 \mathrm{M} \mathrm{NaCl}$

$0.5 \mathrm{M}$ Tris-HCL, $\mathrm{pH} 7.2$

$1.0 \mathrm{mM}$ EDTA 
-for 1 litre

$500 \mathrm{ml} 1.0 \mathrm{M}$ Tris-HCL, pH 7.2

$2.0 \mathrm{ml} 0.5 \mathrm{M}$ EDTA

$87.66 \mathrm{~g} \mathrm{NaCl}$

$2 \mathrm{XD} \mathrm{H}_{2} \mathrm{O}$ to 1 litre

20X SSC

$3.0 \mathrm{M} \mathrm{NaCl}$

$0.3 \mathrm{M}$ sodium citrate

-for 1 litre

$175.3 \mathrm{~g} \mathrm{NaCl}$

88.2 g sodium citrate

- dissolve in $800 \mathrm{ml} 2 \mathrm{XD} \mathrm{H}_{2} \mathrm{O}$

- adjust dropwise $\mathrm{pH}$ to 7.0 with $1 \mathrm{M} \mathrm{HCL}$

$-2 \mathrm{X}_{2} \mathrm{O}$ to 1 litre

- autoclave

Pre-hybridization buffer

- make this solution just prior to use

$6 \times \mathrm{SSC}$

5X Denhart's solution

$0.5 \%$ SDS

- for $50 \mathrm{ml}$ ( $25 \mathrm{ml}$ for pre-hyb., $25 \mathrm{ml}$ for hyb.)

$15.0 \mathrm{ml} 20 \times \mathrm{SSC}$

$2.5 \mathrm{ml} 100 \mathrm{X}$ Denhart's solution

$1.0 \mathrm{ml} 25 \%$ SDS

2XD H2O to $50 \mathrm{ml}$ (sterile) 
- heat to 37 degree $C$ just prior to use

- use $25 \mathrm{ml}$ for pre-hybridization

- denature $0.5 \mathrm{ml}$ sonicated non-homologous salmon sperm DNA $(1.0 \mathrm{mg} / \mathrm{ml})$ by heating in a boiling water bath for $5 \mathrm{mins}$.

- chill on ice and add to pre-hybridization solution just before adding to membrane, or add pre-hybridization solution to bag then add sperm to bag, seal, and swirl by hand to mix.

- use $25 \mathrm{ml}$ for hybridization

- denature labeled probe DNA by heating in a boiling water bath for 5 minutes.

- chill on ice and add to hybridization solution just before adding to membrane.

$2 \times$ SSC

$-100 \mathrm{ml} 20 \mathrm{XSSC}$ in $900 \mathrm{ml} 2 \mathrm{XD} \mathrm{H} 2 \mathrm{O}$

$2 \times \mathrm{SSC} / 0.1 \% \mathrm{SDS}$

- for $500 \mathrm{ml}$

$2.0 \mathrm{ml} 25 \% \mathrm{SDS}$

$2 \times \mathrm{SSC}$ to $500 \mathrm{ml}$

$1 \times \mathrm{SSC} / 0.1 \%$ SDS

- for $500 \mathrm{ml}$

$2.0 \mathrm{ml} 25 \%$ SDS

$1 \mathrm{XSSC}$ to $500 \mathrm{ml}(25 \mathrm{ml} 20 \times \mathrm{SSC}$ in $500 \mathrm{ml} 2 \mathrm{XD} \mathrm{H} 2 \mathrm{O}$ )

Buffer 1 
$0.1 \mathrm{M}$ Tris-HCL pH 7.5

$0.15 \mathrm{M} \mathrm{NaCL}$

- for 1 litre

$100 \mathrm{ml} 1.0 \mathrm{M}$ Tris-HCl pH 7.5

$30.0 \mathrm{ml} 5.0 \mathrm{M} \mathrm{NaCl}$

2XD H2O to 1 litre (sterile)

Buffer 2

$3 \%$ BSA in Buffer 1

- for $100 \mathrm{ml}$

3 g BSA (fraction V)

Buffer 1 to $100 \mathrm{ml}$

Buffer 3

$0.1 \mathrm{M}$ Tris- $\mathrm{HCl}$ pH 9.5

$0.1 \mathrm{M} \mathrm{NaCl}$

$50 \mathrm{mM} \mathrm{MgC12}$

- for 1 litre

$100 \mathrm{ml} 1.0 \mathrm{M}$ Tris-HCL pH 9.5

$20 \mathrm{ml} 5.0 \mathrm{M} \mathrm{NaCl}$

$50 \mathrm{ml} 1.0 \mathrm{M} \mathrm{Mg} \mathrm{C12}$

2XD H2O to 1 litre (sterile)

SA-AP Solution

$10.0 \mathrm{ml}$ Buffer 1

10.0 ul SA-AP 
- make solution just prior to use in $15 \mathrm{ml}$ screw-top polypropylene tube

Dye Solution

$7.5 \mathrm{ml}$ Buffer 3

33 ul NBT

- invert gently

215 ul BCIP

- invert gently

- make solution just prior to use in $15 \mathrm{ml}$ screw-top polypropylene tube

Terminal Solution

$20 \mathrm{mM}$ Tris- $\mathrm{HCl} \mathrm{pH} 7.5$

$0.5 \mathrm{mM}$ EDTA

- for $500 \mathrm{ml}$

$10.0 \mathrm{ml} 1.0 \mathrm{M}$ Tris- $\mathrm{HCl} \mathrm{pH} 7.5$

$0.5 \mathrm{ml} \quad 0.5 \mathrm{M}$ EDTA

2XD H2O to $500 \mathrm{ml}$ (sterile)

Tris-borate (TBE)

-working solution

$0.089 \mathrm{M}$ Tris-borate

$0.089 \mathrm{M}$ boric acid

$0.002 \mathrm{M}$ EDTA

- 10X stock solution

Tris Base

$108 \mathrm{~g}$ 
boric acid

$55 \mathrm{~g}$

$0.5 \mathrm{M}$ EDTA ( $\mathrm{pH} 8.0) \quad 40 \mathrm{~g}$

$2 \mathrm{XD} \mathrm{H} 2 \mathrm{O}$ to 1 litre (sterile)

STE

$10 \mathrm{mM}$ Tris- $\mathrm{HCl} \mathrm{pH} 8.0$

$100 \mathrm{mM} \mathrm{NaCl}(=0.1 \mathrm{M} \mathrm{NaCl})$

$1 \mathrm{mM}$ EDTA pH 8.0

- for $100 \mathrm{ml}$

$-1.0 \mathrm{ml} 1 \mathrm{M}$ Tris- $\mathrm{HCl} \mathrm{pH} 8.0$

$-2.0 \mathrm{ml} 5 \mathrm{M} \mathrm{NaCl}$

$-0.2 \mathrm{ml} 0.5 \mathrm{M}$ EDTA pH 8.0

$2 \mathrm{XD} \mathrm{H} 2 \mathrm{O}$ to $100 \mathrm{ml}$ (sterile)

$25 \%$ SDS

** WEAR MASK WHEN WEIGHING SDS**

- autoclave bottle before using

- dissolve $25 \mathrm{~g}$ electrophoresis grade SDS in $75 \mathrm{ml}$ of sterile 2XD

$\mathrm{H} 2 \mathrm{O}$

- heat to 65 degrees $C$ to assist dissolution

- adjust volume to $100 \mathrm{ml}$

1.0 M MgC12

- $20.33 \mathrm{~g} \mathrm{MgC12} * 6 \mathrm{H} 20$

- dissolve in $100 \mathrm{ml} 2 \mathrm{XD} \mathrm{H} 2 \mathrm{O}$

- autoclave 
3.0 M Sodium Acetate

$40.83 \mathrm{~g} \mathrm{NaOAC}$

- add $30 \mathrm{ml} 2 X D \mathrm{H} 2 \mathrm{O}$

- $\mathrm{pH}$ to 5.2 with glacial acetic acid, dropwise

- 2XD H2O to $100 \mathrm{ml}$

- autoclave

Ethidium Bromide (EtBr)

**WEAR GLOVES AND MASKS WHILE WEIGHING**

- place in $50 \mathrm{ml}$ polypropylene tube

$-0.25 \mathrm{~g} \mathrm{EtBr}$ in $25 \mathrm{ml} 2 \mathrm{XD} \mathrm{H} 2 \mathrm{O}$

- wrap with aluminum foil

- mix on rotor overnight until dissolved

- store at 4 degrees $C$

Denhart's Solution (100X)

- combine the following in a $50 \mathrm{ml}$ polypropylene tube

$1 \mathrm{~g}$ Ficoll

$1 \mathrm{~g}$ polyvinylpyrrolidone

1 g BSA (Pentax fraction V)

sterile $2 X D \mathrm{H} 2 \mathrm{O}$ to $50 \mathrm{ml}$

filter sterilize through a 0.45 sterile filter

Salmon Sperm DNA

$-10 \mathrm{mg} / \mathrm{ml}$ in $\mathrm{H} 2 \mathrm{O}$

- flame scissors, cut and weigh out $10 \mathrm{mg}$ salmon sperm

- put into eppendorf and add $1 \mathrm{ml} 2 \mathrm{XD} \mathrm{H} 2 \mathrm{O}$ (sterile) 
- vortex, let dissolve, vortex, dissolve, etc.

- once in solution, shear DNA using $1 \mathrm{cc}$ syringe and 23 gauge needle

RANDOM PRIMER PROTOCOL

Reaction conditions:

25 - 50 ng single stranded DNA

$50 \mathrm{mM}$ Tris- $\mathrm{HCl} \mathrm{pH} 7.2$

$10 \mathrm{mM} \mathrm{MgCl} 2$

$0.1 \mathrm{mM}$ DTT

$0.2 \mathrm{Mg} / \mathrm{ml} \mathrm{BSA}$

$25 \mathrm{uM}$ each dNTP minus labeled dNTP

$3.1 \mathrm{mg} / \mathrm{ml}$ random primer

2 units of Klenow

Incubate at 37 Degrees $C$ for 30 minutes

Solutions:

5 X Random Priming Buffer

$250 \mathrm{mM}$ Tris- $\mathrm{HCl} \mathrm{pH} 7.2$

$50 \mathrm{mM} \mathrm{MgCl} 2$

$0.5 \mathrm{mM}$ DTT

$1 \mathrm{mg} / \mathrm{ml} \mathrm{BSA}$

$10 \mathrm{X}$ dNTP mix minus labeled dNTP

$250 \mathrm{uM}$ each dNTP 
Random Primer (hexamer)

50 O.D. units into $0.555 \mathrm{ul} 1 \mathrm{mM}$ Tris- $\mathrm{HCl} \mathrm{pH} 7.5$

90 O.D. units $/ \mathrm{ml}=4 \mathrm{ug} / \mathrm{ul}$ primer.

Reaction:

1. Denature the DNA by boiling in water bath for 10 minutes

2. Add 5 ul of $5 \times$ Random Priming Buffer

3. Add $2.5 \mathrm{ul}$ of dNTP mix - label dNTP

4. Add 5 ul of Random Primer, Vortex and quick spin

5. Add $25 \mathrm{uCi}$ of alpha $325 \mathrm{dNTP}$ ( $2.5 \mathrm{ul}$ of $10 \mathrm{mCi} / \mathrm{ml}$ stock)

6. Add 2 units of Klenow, Vortex and quick spin

7. Incubate for $30-60$ minutes at 37 degrees $C$

8. Stop reaction by adding $2 \mathrm{ul}$ of $0.2 \mathrm{M}$ EDTA pH 8.0

9. Denature DNA by boiling for 5 minutes before adding to hybridization solution. 